\title{
ॠUSGS
}

science for a changing world

\section{Shallow-Landslide Hazard Map of Seattle, Washington}

By Edwin L. Harp', John A. Michael', and William T. Laprade

${ }^{1}$ U.S. Geological Survey, Golden, Colorado 80401

${ }^{2}$ Shannon and Wilson, Inc., Seattle, Washington 98103

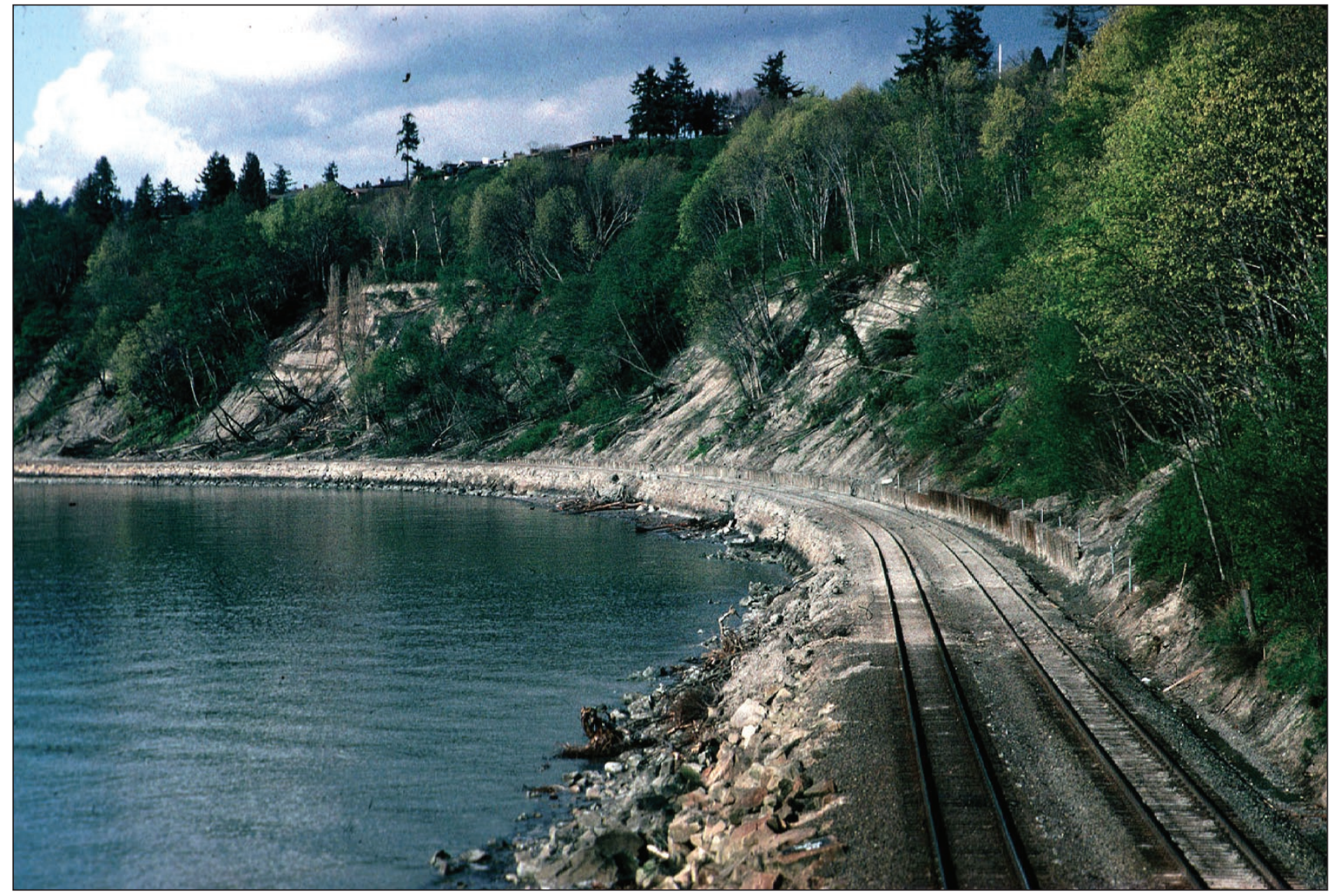

U.S. Geological Survey Open-File Report 2006-1139 


\section{U.S. Department of the Interior \\ Dirk Kempthorne, Secretary}

\section{U.S. Geological Survey \\ P. Patrick Leahy, Acting Director}

U.S. Geological Survey, Reston, Virginia 2006

For product and ordering information:

World Wide Web: http://www.usgs.gov/pubprod

Telephone: 1-888-ASK-USGS

For more information on the USGS - the Federal source for science about the Earth, its natural and living resources, natural hazards, and the environment:

World Wide Web: http://www.usgs.gov

Telephone: 1-888-ASK-USGS

Harp, Edwin L., Michael, John A., and Laprade, William T., 2006, Shallow-Landslide Hazard Map of Seattle, Washington: U.S. Geological Survey OpenFile Report 2006-1139, 18 p., 2 plates, map scale 1:25,000.

Any use of trade, firm, or product names is for descriptive purposes only and does not imply endorsement by the U.S. Government.

Although this report is in the public domain, permission must be secured from the individual copyright owners to reproduce any copyrighted material contained within this report.

Cover photograph: Slopes along Puget Sound north of Carkeek Park where numerous debris flows have traveled downslope and across the tracks of the Burlington-Northern-Santa Fe Railroad. 


\section{Contents}

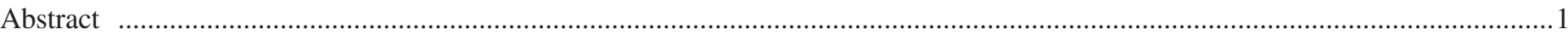

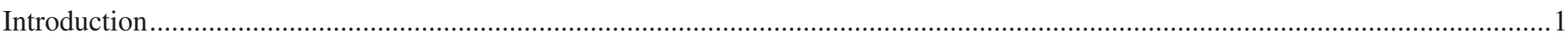

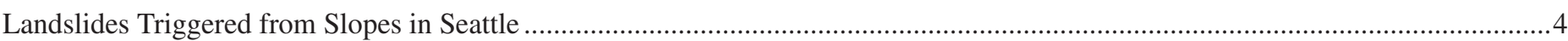

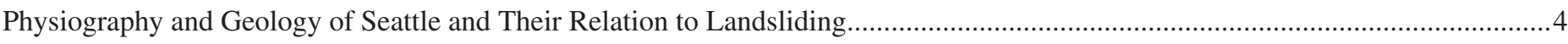

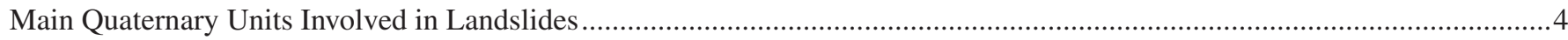

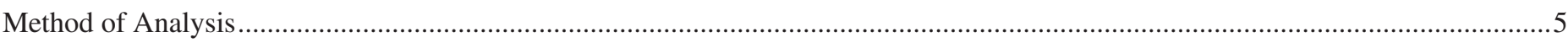

Previous Work

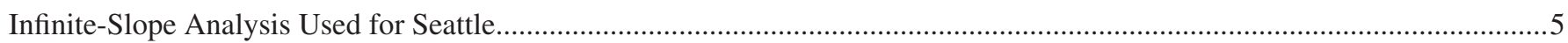

Necessary Databases

Geology

Shear-Strength Data

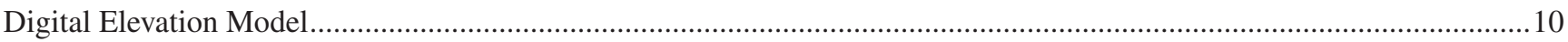

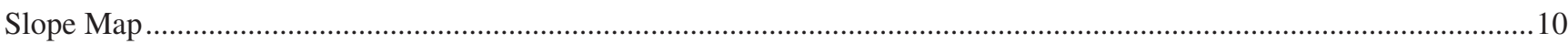

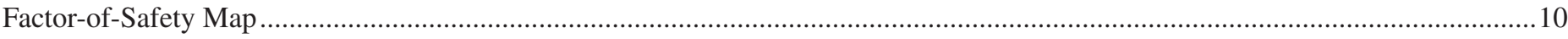

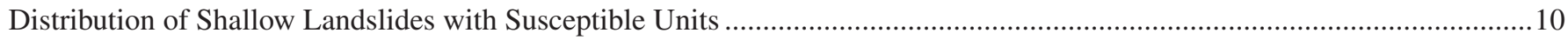

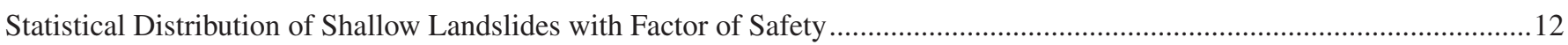

Comparison of Factor of Safety with Variable Strength Properties versus Slope Alone as a Predictor of Hazard.......................13

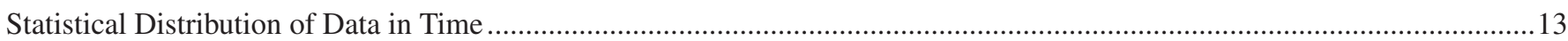

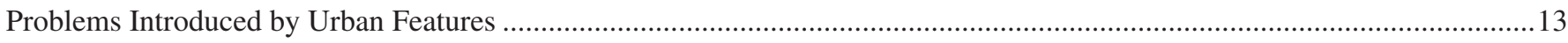

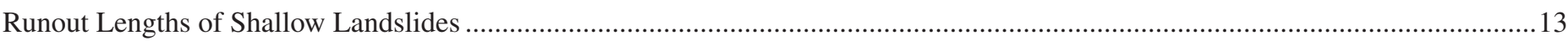

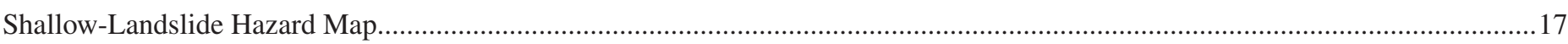

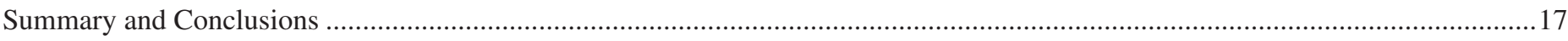

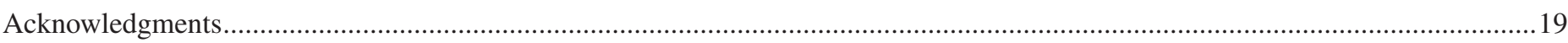

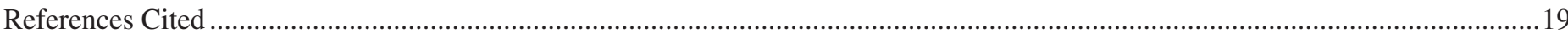

\section{Figures}

1. Slump/debris flow near Woodway, Washington, that overran several freight cars of the Burlington-Northern-Santa Fe railroad on January 17, 1997. The train was almost through the slide area when the last few cars were hit by the debris flow ........................

2. Shallow debris flow that initiated above Rolling Bay Walk on Bainbridge Island. It destroyed the house at the foot of the slope

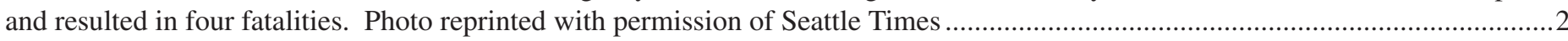

3. Shaded relief map of Seattle study area with location names discussed in text ............................................................................

4. Idealized cross section of typical Puget Sound bluff in Seattle showing relationship of perched water tables to the Advance

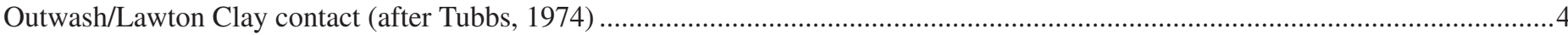

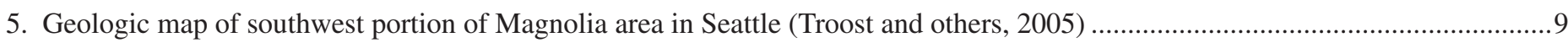

6. Slope map of southwest portion of Magnolia area in Seattle .............................................................................................

7. Shallow landslide susceptibility map of southwest portion of Magnolia area in Seattle depicting FS values of cells.....................11

8. Bar chart showing number of shallow landslides from Seattle landslide data set versus FS value ..............................................12

9. A, Bar chart showing number of shallow landslides per square kilometer from Seattle landslide data set versus FS value.

$\mathrm{B}$, Scatter plot of the data in A with an exponential curve fit to the data.

10. A, Bar chart showing number of shallow landslides per square kilometer from Seattle landslide data set versus FS value with shear strength held constant. B, Scatter plot of the data in A with an exponential curve fit to the data.....................................15

11. Bar chart showing the number of shallow landslides from the Seattle landslide data set versus the year of occurrence................16

12. Cumulative frequency plot of runout distances for the 326 debris-flow runout lengths mapped from north Seattle to Everett ......16

13. Map of relative shallow-landslide hazard for southwest portion of Magnolia area in Seattle .....................................................18

\section{Table}

1. Shear Strengths Assigned to Geologic Units in the Seattle Area 


\title{
Shallow-Landslide Hazard Map of Seattle, Washington
}

\author{
By Edwin L. Harp', John A. Michael', and William T. Laprade ${ }^{2}$
}

${ }^{1}$ U.S. Geological Survey, Golden, Colorado 80401

${ }^{2}$ Shannon and Wilson, Inc., Seattle, Washington 98103

\section{ABSTRACT}

Landslides, particularly debris flows, have long been a significant cause of damage and destruction to people and property in the Puget Sound region. Following the years of 1996 and 1997, the Federal Emergency Management Agency (FEMA) designated Seattle as a "Project Impact" city with the goal of encouraging the city to become more disaster resistant to the effects of landslides and other natural hazards. A major recommendation of the Project Impact council was that the city and the U.S. Geological Survey (USGS) collaborate to produce a landslide hazard map of the city. An exceptional data set archived by the city, containing more than 100 years of landslide data from severe storm events, allowed comparison of actual landslide locations with those predicted by slope-stability modeling. We used an infinite-slope analysis, which models slope segments as rigid friction blocks, to estimate the susceptibility of slopes to shallow landslides which often mobilize into debris flows, water-laden slurries that can form from shallow failures of soil and weathered bedrock, and can travel at high velocities down steep slopes. Data used for analysis consisted of a digital slope map derived from recent Light Detection and Ranging (LIDAR) imagery of Seattle, recent digital geologic mapping, and shearstrength test data for the geologic units in the surrounding area. The combination of these data layers within a Geographic Information System (GIS) platform allowed the preparation of a shallow landslide hazard map for the entire city of Seattle.

\section{INTRODUCTION}

The glacial bluffs bordering Puget Sound within the city of Seattle have long been recognized as susceptible to shallow landslides that often transform into debris flows triggered by periods of intense rainfall or rapid snowmelt. Debris flows have caused significant damage to people and property in Seattle and

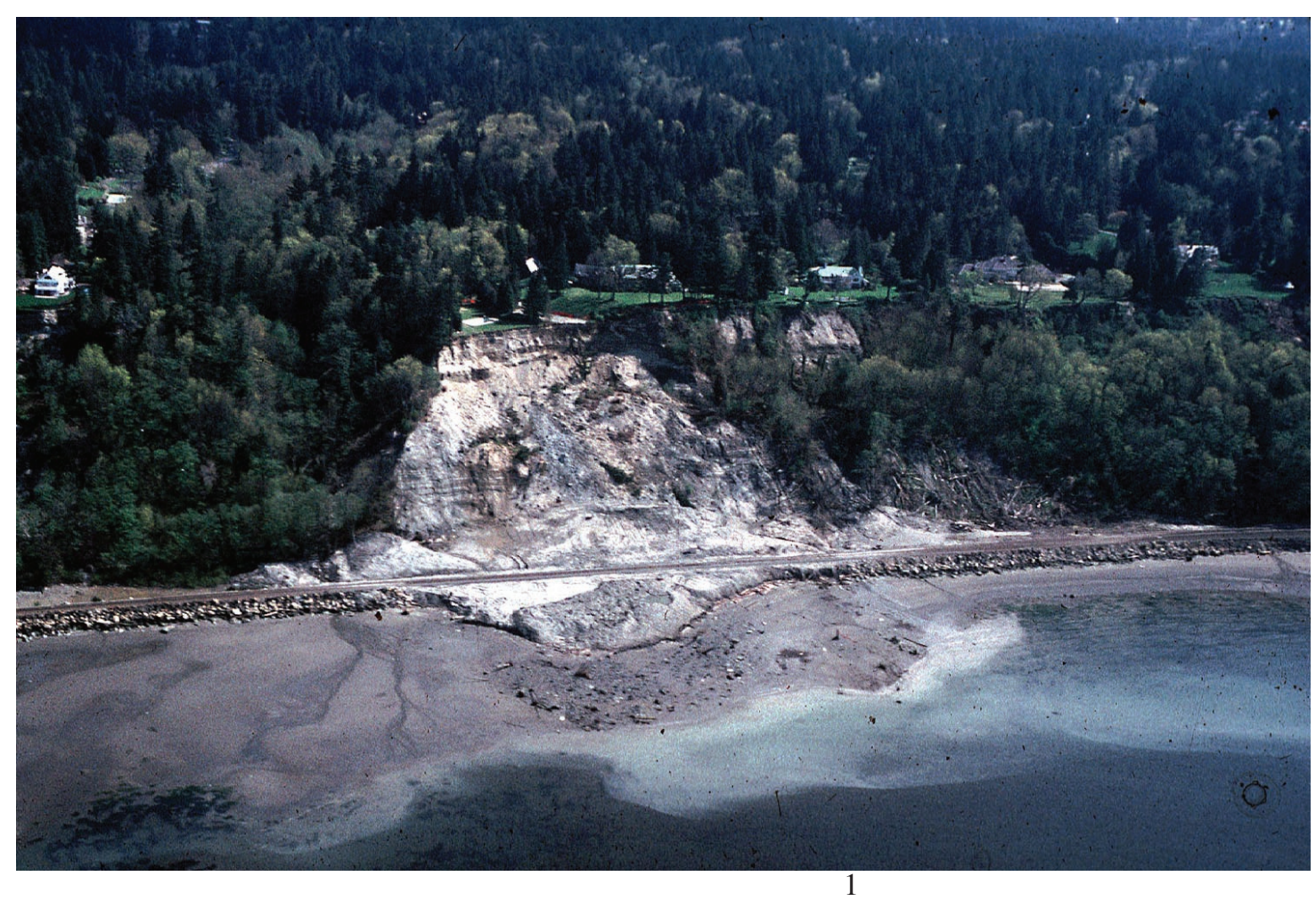

Figure 1. Slump/debris flow near Woodway, Washington, that overran several freight cars of the Burlington-NorthernSanta Fe railroad on January 17, 1997. The train was almost through the slide area when the last few cars were hit by the debris flow. 
will continue to do so in the future. Severe episodes of intense precipitation are frequent enough in Seattle that a quantitative method to estimate the spatial hazard from shallow landslides is necessary to ensure future prudent and efficient land-use and emergency-response decisions.

The role of landslides, once again causing destruction and damage to people and property in the Pacific Northwest became readily apparent in the early months of 1996 and 1997. During the week of February 4, 1996, sustained heavy rainfall on a late-season snowpack in the Cascade Range of Washington and Oregon, and three to four days of heavy rainfall (with cumulative rainfall totals in excess of $685 \mathrm{~mm}$; Taylor, 1996) at lower elevations caused more than $\$ 300$ million damage from the combined effects of flooding and landsliding (FEMA Interagency Hazard Mitigation Team, 1996). After 450-600 $\mathrm{mm}$ of snow had fallen in the Puget Lowland of northwest Washington near Seattle in late December 1996, the snow changed to rain and, beginning on December 29, $25 \mathrm{~mm} /$ day of rain fell for the next three days at Seatac Airport (Lott and others, 1997). The rain rapidly melted the snow causing infiltration of the snowmelt and widespread flooding and landsliding in January and mid-March 1997, as additional rain triggered more landslides. Notable landslides triggered by these storms included the Woodway slump/ debris flow (fig. 1), which derailed five cars of a Burlington-Northern-Santa Fe freight train, and a highly publicized debris flow on Bainbridge Island at Rolling Bay Walk that killed a family of four (Baum and others, 1998, fig. 2).

Shortly after these two years of flooding and landslide damage, the Federal Emergency Management Agency (FEMA) designated Seattle as a "Project Impact" city and followed up with a \$1 million grant to stimulate additional funding and to form a Project Impact Council consisting of public and private partners committed to building a more disaster-resistant city. A major recommendation of this council was that the U.S. Geological Survey (USGS) and the city of Seattle work together to produce a landslide hazard map of the area (fig. 3). A major factor in promoting this effort was the existence of a database spanning more than 100 years, maintained by the city of Seattle, consisting of locations and other information about landslides that had been triggered by major storms. These data were compiled into a database using a Geographic Information System (GIS) format by Shannon and Wilson, Inc. for the City of Seattle (Nashem and Laprade, 1998; Laprade and others, 2000) and are used in this report to compare with our analysis of the shallow landslide processes that commonly mobilize as debris flows.

This study uses this database, together with geotechnical and slope data, to derive a susceptibility map and subsequently a relative hazard map for shallow landslides in Seattle. These maps, published at a scale of 1:25,000 (Map Sheets 1, and 2), show similar patterns to those prepared by Montgomery and others (2001) showing theoretical critical rainfall levels in Seattle,

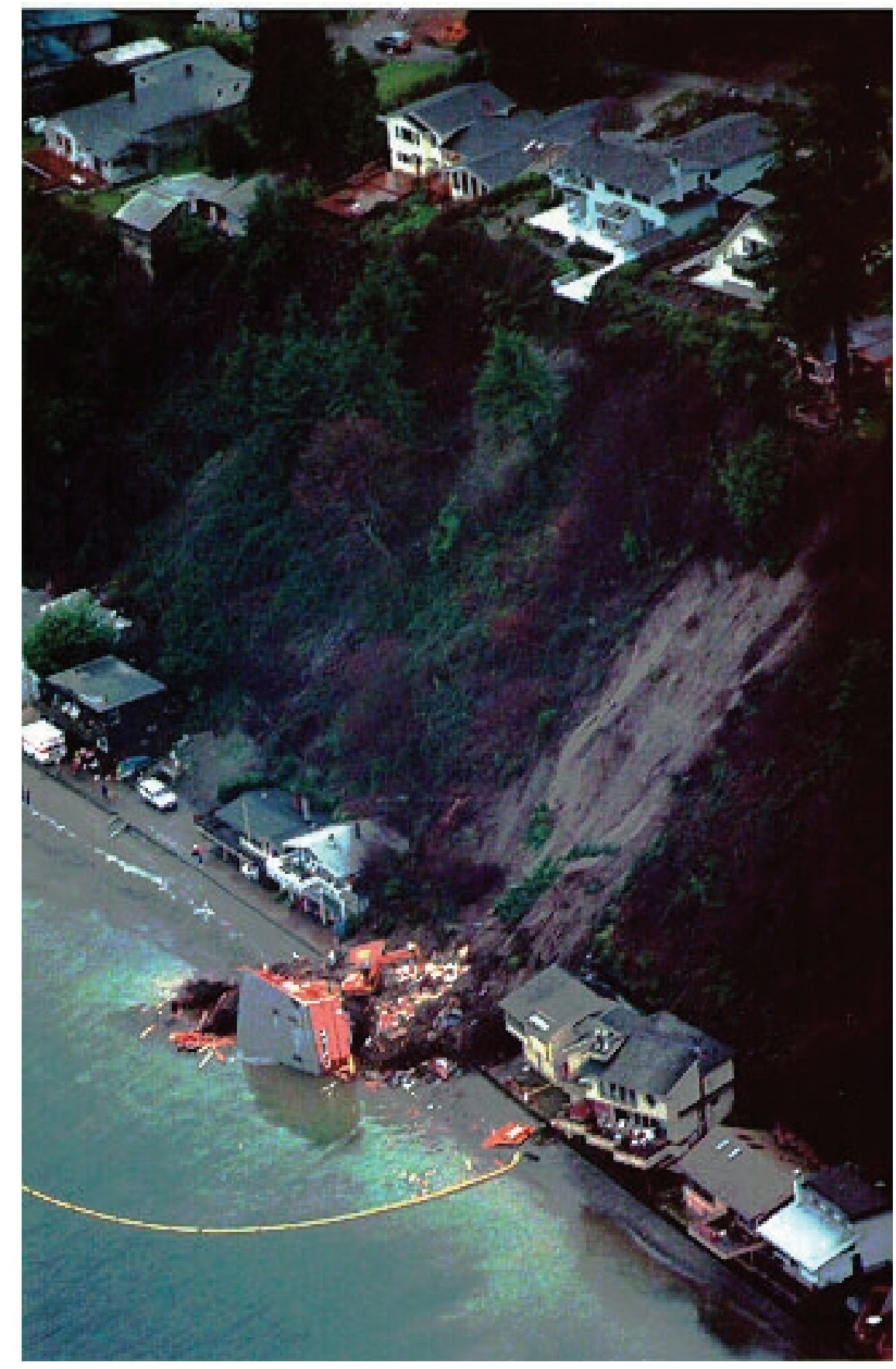

Figure 2. Shallow debris flow that initiated above Rolling Bay Walk on Bainbridge Island. It destroyed the house at the foot of the slope and resulted in four fatalities. Photo reprinted with permission of Seattle Times. 
Figure 3. Shaded relief map of Seattle study area with location names discussed in text.

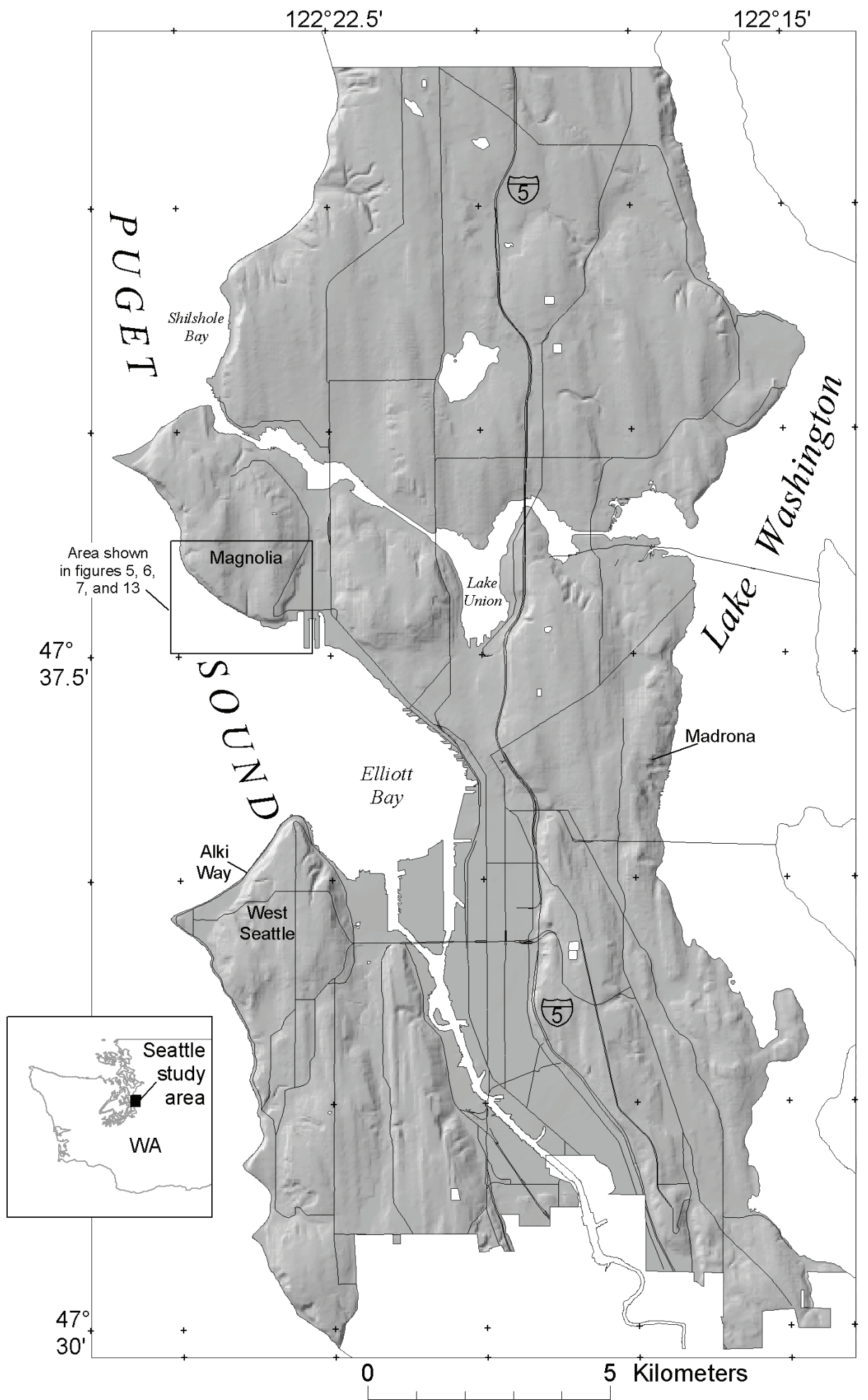


but they exhibit a greater level of detail due to the availability of more recent topographic and geologic data and the use of spatially variable geotechnical properties.

\section{LANDSLIDES TRIGGERED FROM SLOPES IN SEATTLE}

Most landslides that occur in the Puget Lowland and in the city of Seattle are shallow slope failures that commonly mobilize into debris flows, which are fluid mixtures of water and soil. Debris flows in the Seattle area contain a wide variety of particle sizes ranging from clay-sized to cobbles. The average thickness of shallow failures that form debris flows is $2.4 \mathrm{~m}$ as established by observations and measurements during field reconnaissance. The fluid mixtures that result from the mixing of slope materials and water can travel at velocities as high as $60 \mathrm{~km} / \mathrm{hr}$, making them one of the most hazardous types of landslides to people and property. For the purpose of this paper, the term shallow landslide refers to those landslides (either rotational or translational) that have mobilized or could potentially mobilize into a debris flow.

The analysis we used to prepare a debris-flow hazard map for Seattle is restricted to the shallow $(2.4 \mathrm{~m})$ failures that commonly form debris flows. Our analysis uses a digital geologic database, shear-strength values for all of the geologic units, a slope map prepared from a Digital Elevation Model (DEM), and the landslide database noted above. The DEM was derived from recent Light Detection and Ranging (LIDAR) data. All of the data points used in our analysis from the landslide database were restricted to shallow failures that formed debris flows or that could potentially form debris flows, totaling 1,316 failures. The locations of failures from the database consist of point locations, not polygons, which prevents detailed analysis of spatial probability.

\section{PHYSIOGRAPHY AND GEOLOGY OF SEATTLE AND THEIR RELATION TO LANDSLIDING}

The Seattle area is dominated by north-trending elongate ridges and uplands. Between the uplands are Pleistocene glacial troughs occupied by tidewaters, lakes, and streams following the retreat of the most recent (Vashon Stade) glacial ice. The major troughs are occupied by the main body of Puget Sound, the Duwamish-Green River valley with Elliot Bay at its mouth, Lake Washington, and Lake Sammamish. The intervening uplands are occupied by glacial drift deposits (Galster and Laprade, 1991).

\section{Main Quaternary Units Involved in Landslides}

The main glacial units exposed in the Seattle area are those of the Vashon Stade of the Fraser glaciation (Galster and Laprade, 1991). These are (from oldest to youngest) the Lawton Clay, Esperance Sand or advance outwash, Vashon Till, and recessional outwash deposits. Since most of the ridges and uplands in the Seattle area are comprised of these deposits, they play a major role in the formation of landslides in Seattle.

The Lawton Clay consists of laminated to massive dark-gray clay and light-gray silt. It crops out on most of the steep Puget Sound bluffs of the Seattle area and ranges in thickness from 0 to $30 \mathrm{~m}$ (Galster and Laprade, 1991). It overlies Olympia nonglacial sediment and, in many areas, forms an aquiclude, perching groundwater at its contact with the overlying sandy advance outwash deposits. This tendency to inhibit the downward flow of groundwater and to produce springs at the above-mentioned contact commonly results in the generation of landslides at this horizon (see fig. 4).

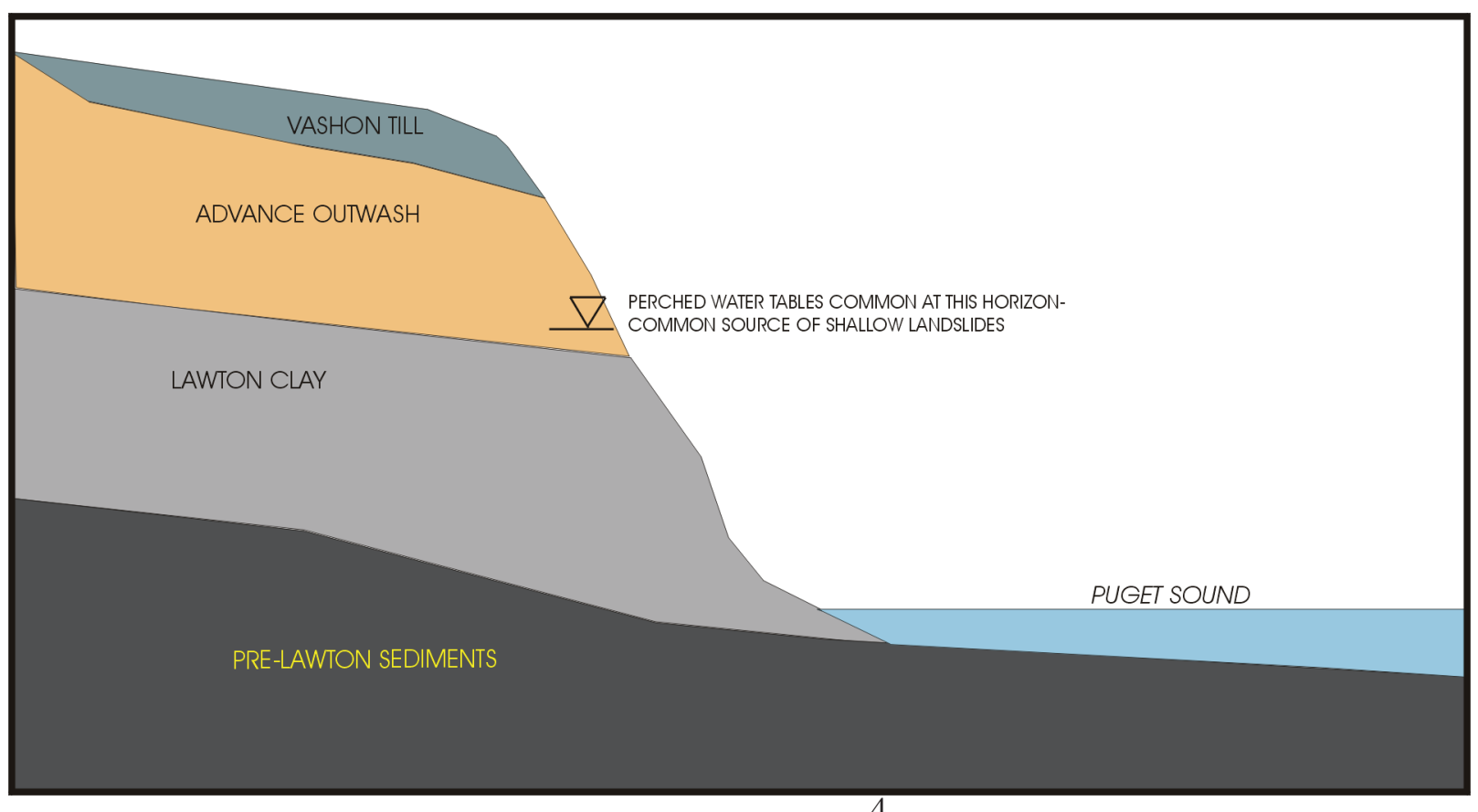

Figure 4. Idealized cross section of typical Puget Sound bluff in Seattle showing relationship of perched water tables to the Advance Outwash/Lawton Clay contact (after Tubbs, 1974). 
The advance outwash deposits of the Vashon glaciation, the Esperance Sand, consist of fine to medium sand with local silt beds and lenticular channels of gravel. The lower contact with the Lawton Clay is gradational. As previously mentioned, the Esperance Sand commonly serves as an aquifer at whose base ground-water flow emerges on steep bluffs throughout the Puget Lowland. Thickness of the sand averages about $75 \mathrm{~m}$. The Esperance Sand commonly underlies the Vashon Till, which caps many of the ridges in the area. The Vashon Till was deposited as the ground moraine of the Vashon glaciation and ranges from a gravely, sandy silt to silty sand with varied amounts of clay and scattered cobbles and boulders. It ranges from a few meters to more than $9 \mathrm{~m}$ in thickness. The deposits are relatively resistant to erosion and commonly form steep cliffs having near-vertical slopes (Galster and Laprade, 1991).

The recessional outwash deposits of the Vashon glaciation consist of gravel and sand that generally are confined to major glacial troughs but also occur irregularly on drift uplands.

Locally, the deposits reach thicknesses of more than $60 \mathrm{~m}$ in the major outwash channels. They include coarse outwash deltas, kame terraces, and other ice-contact deposits along certain ridge flanks. They also contain fluvial outwash and associated kettles on drift upland; some deposits contain Holocene peat and local fine sand and silt deposited in ephemeral ice-marginal lakes (Galster and Laprade, 1991).

The mass-wastage geologic unit is characterized by indistinct topography produced by landslide, colluvial soil movement, and other gravitational processes (Troost and others, 2005). The landslide deposits are those distinct landslides that are large enough or recent enough to be recognized and mapped.

Nearly all of the Quaternary deposits that comprise the slopes in Seattle, both glacial and non-glacial, are uncemented or only weakly cemented. Therefore, the sandy and gravelly deposits containing little or no clay tend to have low or no cohesion. The main contribution to their shear strength is the internal angle of friction, which for sand and gravel typically ranges from $30^{\circ}$ to $40^{\circ}$. Deposits containing significant clay fractions tend to have moderate to high cohesion values ranging from 10 to $50 \mathrm{kPa}$.

\section{METHOD OF ANALYSIS}

\section{Previous Work}

There are a number of methods commonly used in GIS analyses to estimate the stability of slopes that are divided into grid cells. Many of these methods calculate the Factor of Safety (FS) of each cell. FS is the ratio of the forces resisting slope movement to the forces driving it. Thus, FS values greater than 1.0 indicate stability while those less than 1.0 indicate instability. Therefore, the greater the FS value the more stable the slope. SINMAP (Pack and others, 1999) and SHALSTAB (Montgomery and Dietrich, 1994) are two similar programs that predict slope stability using an infinite-slope analysis. SINMAP uses ranges of rainfall and material properties expressed as uniform probability distributions. Both models use the same equation to calculate the factor of safety (FS) for each grid cell in a GIS layer:

$$
F S=\frac{\left.C_{r}+C_{s}+\cos ^{2} \alpha{ }_{\gamma_{s}}\left(D-D_{w}\right)+\left(\gamma_{s}-\gamma_{w}\right) D_{w}\right] \tan \phi^{\prime}}{\sin \alpha \cos \alpha\left(\gamma_{s} D\right)}
$$

Where $C_{r}$ and $C_{s}$ are root strength and soil cohesion, respectively, $\mathrm{D}$ is the vertical soil-depth thickness, $D_{w}$ is the vertical thickness of the saturated layer, and $\gamma$ is the unit weight of soil $(s)$ and water $(w)$. Both methods assume groundwater flow parallel to existing slopes. The variables $\alpha$ and $\phi^{\prime}$ are the slope and effective friction angles, respectively. Montgomery and others (2001) used SHALSTAB to estimate critical steady-state rainfall for slope instability in Seattle and compared the predicted unstable slopes with the locations of landslides from the database of Shannon and Wilson (Laprade and others, 2000). Their analysis used constant values for material properties such as cohesion, soil transmissivity, internal angle of friction, and material unit weights.

Level I Stability Analysis (LISA; Hammond and others, 1992) is another infinite slope analysis developed by the USDA Forest Service that calculates a probability for failure of slope cells from different combinations of variables within the infiniteslope equation, each with their own probability distribution. This analysis was one of several models used by Morrissey and others (2001) to predict debris flows in Madison County, Virginia. This model uses essentially the same equation for factor-of-safety as SINMAP and SHALSTAB except that a term for tree surcharge is introduced.

Yet another method is Iverson's transient-response model (Iverson, 2000), which links a pore-pressure response function with the governing factor-of-safety equation. The pore-pressure response function is determined by applying a fixed rainfall intensity for a specified period of time into a one-dimensional infiltration equation using an estimate of soil hydraulic diffusivity. A modification of this method has been produced by Baum and others (2002) for tension-saturated soils using varying rainfall intensities (for example, real storm rainfall intensities and durations) and by Savage and others (2004) for soils having unsaturated zones. These models allow calculation of factorof-safety at different depths in the soil column and at different times in the rainfall period. These models require an estimate of the hydraulic properties of the existing soils (which can vary one to two orders of magnitude even within materials of uniform texture; Reid, 1997) and the initial pore-pressure distribution, parameters that are not commonly available for most slopes.

\section{Infinite-Slope Analysis used for Seattle}

We used a simpler version of the factor-of-safety equation as suggested by Jibson and others (2000) because we do not have soil hydraulic-property data for all of Seattle nor is there only one intensity/duration condition for rainfall that is required to trigger shallow landslides. Rather, a spectrum of intensity/ duration conditions exist which can trigger debris flows and other shallow landslides in Seattle (Godt and others, 2006). We do, 
Table 1. Shear strengths assigned to geologic units in the Seattle area.

\begin{tabular}{|c|c|c|c|}
\hline SYMBOL & UNIT OR FORMATION NAME & $\begin{array}{c}\phi^{\prime} \\
i \text {-initial } \\
f \text {-final }\end{array}$ & $\begin{array}{c}c^{\prime}(\mathrm{kPa}) \\
i \text {-initial } \\
f \text {-final }\end{array}$ \\
\hline af & Artificial fill & $30^{\circ}$ & 14.4 \\
\hline afm & Modified land (compacted fill, retaining walls) & $34^{\circ}$ & 47.9 \\
\hline afl & Landfill & $30^{\circ}$ & 14.4 \\
\hline afr & Artificial fill in historic river channels & $26^{\circ}$ & 4.8 \\
\hline Qw & Wetland deposits & $24^{\circ}$ & 9.6 \\
\hline Qp & Peat (in subsurface) & $24^{\circ}$ & 24.0 \\
\hline $\mathrm{Qb}$ & Beach deposits & $34^{\circ}$ & 0 \\
\hline Qbu & Uplifted beach deposits & $34^{\circ}$ & 0 \\
\hline Qmw & Mass wastage (generally landslides) & $\begin{array}{l}i-30^{\circ} \\
f-32^{\circ}\end{array}$ & $\begin{array}{l}i-24.0 \\
f-19.2\end{array}$ \\
\hline Qls & Landslide deposits & $\begin{array}{l}i-30^{\circ} \\
f-32^{\circ}\end{array}$ & $\begin{array}{l}i-24.0 \\
f-19.2\end{array}$ \\
\hline Qtf & Tide-flat deposits & $24^{\circ}$ & 19.2 \\
\hline Qal & Alluvium & $32^{\circ}$ & 0 \\
\hline Q1 & Lake deposits & $24^{\circ}$ & 19.2 \\
\hline Qf & Fan deposits & $30^{\circ}$ & 9.6 \\
\hline Qt & Terrace deposits & $30^{\circ}$ & 0 \\
\hline Qvr & Vashon recessional outwash deposits & $\begin{array}{l}i-32^{\circ} \\
f-34^{\circ}\end{array}$ & $\begin{array}{c}i-4.8 \\
f-14.4\end{array}$ \\
\hline Qvrl & Vashon recessional lacustrine deposits & $24^{\circ}$ & 19.2 \\
\hline Qvrc & Vashon recessional coarse-grained deposits & $34^{\circ}$ & 14.4 \\
\hline Qvi & Vashon ice-contact deposits & $30^{\circ}$ & 28.7 \\
\hline Qvt & Vashon till & $\begin{array}{l}i-36^{\circ} \\
f-33^{\circ}\end{array}$ & 95.8 \\
\hline
\end{tabular}




\begin{tabular}{|c|c|c|c|}
\hline SYMBOL & UNIT OR FORMATION NAME & $\begin{array}{c}\phi^{\prime} \\
i \text {-initial } \\
f \text {-final }\end{array}$ & $\begin{array}{c}c^{\prime}(\mathrm{kPa}) \\
i \text {-initial } \\
f \text {-final }\end{array}$ \\
\hline Qvtm & Vashon subglacial meltout till & $33^{\circ}$ & 19.2 \\
\hline Qva & Vashon advance outwash deposits (Esperance Sand) & $\begin{array}{l}i-34^{\circ} \\
f-38^{\circ}\end{array}$ & $\begin{array}{l}i-12.0 \\
f-19.2\end{array}$ \\
\hline Qvlc & Vashon Lawton clay of Mullineaux and others (1965) & $26^{\circ}$ & $\begin{array}{l}i-14.4 \\
f-28.7\end{array}$ \\
\hline Qpf & Pre-Fraser glaciation deposits & $34^{\circ}$ & 19.2 \\
\hline Qpfc & Pre-Fraser coarse-grained deposits & $38^{\circ}$ & 19.2 \\
\hline Qpff & Pre-Fraser fine-grained deposits & $26^{\circ}$ & 28.7 \\
\hline Qpfn & Pre-Fraser nonglacial deposits & $34^{\circ}$ & 19.2 \\
\hline Qpfnc & Pre-Fraser coarse-grained nonglacial deposits & $36^{\circ}$ & 19.2 \\
\hline Qpfnf & Pre-Fraser fine-grained nonglacial deposits & $26^{\circ}$ & 28.7 \\
\hline Qob & Olympia beds of Minard and Booth (1988) & $34^{\circ}$ & 19.2 \\
\hline Qpo & Pre-Olympia deposits & $34^{\circ}$ & 19.2 \\
\hline Qpof & Pre-Olympia fine-grained deposits & $26^{\circ}$ & 28.7 \\
\hline Qpoc & Pre-Olympia coarse-grained deposits & $36^{\circ}$ & 19.2 \\
\hline Qpog & Pre-Olympia glacial deposits & $33^{\circ}$ & 28.7 \\
\hline Qpogc & Pre-Olympia coarse-grained glacial deposits & $38^{\circ}$ & 19.2 \\
\hline Qpogf & Pre-Olympia fine-grained glacial deposits & $26^{\circ}$ & 28.7 \\
\hline Qpogt & Pre-Olympia glacial till & $33^{\circ}$ & 95.8 \\
\hline Qpogd & Pre-Olympia glacial diamict & $33^{\circ}$ & 19.2 \\
\hline Qpon & Pre-Olympia nonglacial deposits & $34^{\circ}$ & 19.2 \\
\hline
\end{tabular}




\begin{tabular}{|c|l|c|c|}
\hline SYMBOL & \multicolumn{1}{|c|}{ UNIT OR FORMATION NAME } & $\begin{array}{c}\phi^{\prime} \\
i \text {-initial } \\
f \text {-final }\end{array}$ & $\begin{array}{c}c^{\prime}(\mathrm{kPa}) \\
i \text {-initial } \\
f \text {-final }\end{array}$ \\
\hline Qponc & Pre-Olympia coarse-grained nonglacial deposits & $36^{\circ}$ & 19.2 \\
\hline Qponf & Pre-Olympia fine-grained nonglacial deposits & $26^{\circ}$ & 28.7 \\
\hline Qpone & Pre-Olympia nonglacial estuarine deposits & $30^{\circ}$ & 19.2 \\
\hline Qpd & Possession Drift of Easterbrook and others (1967) & $33^{\circ}$ & 19.2 \\
\hline Qpdf & Possession Drift glaciolacustrine deposits & $26^{\circ}$ & 28.7 \\
\hline Qhc & Hamm Creek Formation (nonglacial ash, silt) & $32^{\circ}$ & 19.2 \\
\hline Tbh & $\begin{array}{l}\text { Blakely Harbor Formation of Fulmer (1975) (basaltic } \\
\text { conglomerate, volcanic silt, hard to soft) }\end{array}$ & $30^{\circ}$ & 19.2 \\
\hline Tb & Blakeley formation of Weaver (1916) & $42^{\circ}$ & 57.5 \\
\hline Tva & Andesite & $\begin{array}{l}\text { Tukwila Formation of Vine (1962) (volcanic breccias, coal } \\
\text { measures, clay seams) }\end{array}$ & 47.9 \\
\hline & & $40^{\circ}$ & 28.7 \\
\hline
\end{tabular}

Conversion: $1 \mathrm{kPa}=20.88 \mathrm{lb} / \mathrm{ft}^{2}$. 
however, have test data from Shannon and Wilson, Inc. (J. Wu, oral communication, 2004) regarding the range of shear strengths of the various geologic units that are present in the Seattle area (table 1). Therefore, we assign each geologic unit an average shear strength in terms of a cohesion $\left(\mathrm{c}^{\prime}\right)$ and internal angle of friction $\left(\phi^{\prime}\right)$ based on the data from Shannon and Wilson, Inc. Our equation takes the form:

$$
F S=\frac{c^{\prime}}{\gamma t \sin \alpha}+\frac{\tan \phi^{\prime}}{\tan \alpha}-\frac{m \gamma_{w} \tan \phi^{\prime}}{\gamma \tan \alpha}
$$

where $F S, \alpha$, and $\gamma_{w}$, are the same as in eq $1, \gamma$ is the unit weight of slope material, $c^{\prime}$ is the effective cohesion of the slope material, $\phi^{\prime}$ is the effective friction angle of the slope material, $t$ is the slope-normal thickness of the potential landslide block, and $m$ is the proportion of the slope thickness that is saturated (Jibson and others, 2000; Harp and others, 2002; Harp and others, 2004). This analysis assumes that groundwater flow is parallel to the ground surface and that the stability of each cell is independent of the cells surrounding it. The landslide data set was inspected to eliminate all landslides that were not shallow failures or that did not occur on natural slopes.
In evaluating $F S$ using eq $2, \gamma$, the unit weight of slope material was assigned the value of $15.7 \mathrm{kN} / \mathrm{m}^{3}$ under dry conditions and $18.8 \mathrm{kN} / \mathrm{m}^{3}$ under saturated conditions, which is consistent with the average dry and wet unit weights of geologic units in Seattle (Galster and Laprade, 1991; Savage and others, 2000). We used an average thickness of $2.4 \mathrm{~m}$ for $t$ to reflect the average thickness of debris flows. The factor of safety was then calculated by inserting values for friction, cohesion, and slope angle in eq 2 for each cell in the model. To accomplish this, the following databases were necessary:

\section{Necessary Databases}

\section{Geology}

A digital geologic map of Seattle at a scale of 1:12,000 (Troost and others, 2005; fig. 5) forms the basis for assigning material properties (shear strengths) to each of the geologic units. Representative values of cohesion and friction angle were assigned as shear-strength components to each geologic unit.

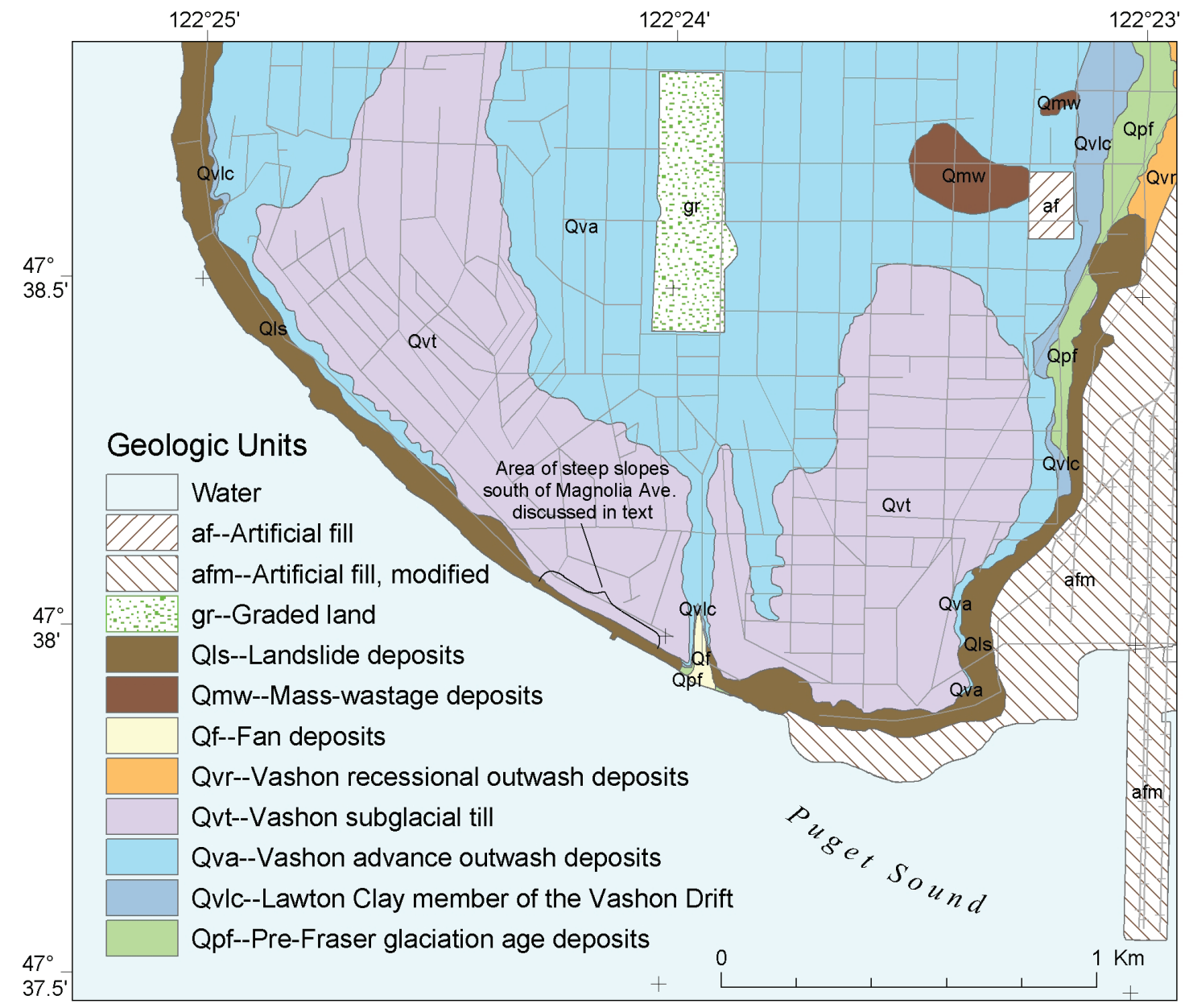

Figure 5. Geologic map of southwest portion of Magnolia area in Seattle (Troost and others, 2005). 


\section{Shear-Strength Data}

Shear-strength values for each of the geologic units (table 1) were selected based on an archived database of shear-strength tests performed by geotechnical consultants (J. Wu, Shannon and Wilson, Inc., oral communication, 2004). Our original assignment of cohesion and friction-angle values to these units reflects a choice of values near the average values reported. Not all of the units in the table were separately defined with associated shear-strength values. Since the advent of the new geologic map for Seattle (Troost and others, 2005), we have arrived at shearstrength values for these newly defined units in consultation with Jim Wu and others at Shannon and Wilson, Inc. These values were then adjusted, if necessary, to preserve static stability of slopes under dry conditions. We imposed the constraint of having few or no slope cells having $F S$ values less than 1.0 under dry conditions, which is consistent with the fact that all of the landslides in Seattle have occurred during the winter rainfall season, except for human-induced landslides. In addition, some iterative adjustments were made in cohesion and friction-angle values to reflect the spatial density of failure locations from the data set and thereby improve the fit of the model. Table 1 shows the cohesion and friction-angle values assigned as shear-strength parameters to each of the geologic units in the Seattle area (not all units listed in the table are present in fig. 5). For those units where the shear strengths were adjusted, the initial and final values are shown in the columns marked $\phi^{\prime}$ and $c^{\prime}$ in the table.

For certain units it was difficult to assign single values for cohesion and friction angle. Artificial fill is so variable in its properties that it cannot be adequately represented as a single value. However, there is no map or data set that depicts this extreme variability. Therefore, we have chosen to represent it using values of cohesion and friction angle that describe its mostly coarse-grained nature $\left(c^{\prime}=14.7 \mathrm{kPa}, \phi^{\prime}=30^{\circ}\right)$, even though it varies from sandy fill, with essentially no cohesion, to agglomerations of concrete rubble and railroad ties, for example. Graded or regraded units also presented problems in that the fill derived from the grading would logically be assigned a shear strength typical of artificial fill, but the "cut" part of the graded slope should be assigned the shear strength of its parent unit. The problem with this is that there is no demarcation within these units to indicate where the "fill" portions end and the "cut" portions begin. Therefore, we have somewhat arbitrarily assigned these units the same shear-strength values as artificial fill. Where fill has been extensively compacted or stabilized with concrete-reinforcement walls or other structural support, the unit has been designated afm, the m meaning "modified". In these cases the unit has been assigned a cohesion of $47.9 \mathrm{kPa}$ to reflect the increase in stability of the unit by compaction or structural reinforcement.

\section{Digital Elevation Model}

The high-resolution 1.83-m digital elevation model (DEM) was produced from recently acquired LIDAR data for the Seattle area. The LIDAR files were obtained from the Puget Sound LIDAR Consortium. The DEM is a grid of square cells of respective elevations with $1.83-\mathrm{m}$ spacings, which is a highresolution database that is adequate for geologic and hydrologic mapping and calculation of slopes commensurate with a horizontal scale of 1:12,000 and a vertical accuracy on the order of $0.3 \mathrm{~m}$ (Puget Sound LIDAR Consortium Website, http://duff. geology.washington.edu/data/raster/lidar/). This DEM was used to prepare a slope map. Compared to a commonly obtained scan of 1:24,000-scale topographic maps with 10-m spacing, the resulting DEM with 1.83-m cell spacing from this LIDAR data is more accurate when used to produce a slope map (Haneberg, 2005).

\section{Slope Map}

The slope map (fig. 6) was produced by applying a simple algorithm modified from a GIS program (Jibson and others, 2000) to the DEM that compares the elevation of adjacent cells and computes the maximum slope. Although slope maps tend to underestimate the steepest slopes, this tendency should be reduced because of the small cell size of this DEM.

\section{FACTOR-OF-SAFETY MAP}

Factor of Safety (FS) as calculated according to eq 2 is shown for each 1.8-m cell in fig. 7 and Map Sheet 1. Different colors represent the ranges of FS. For our analysis, we assume uniform soil-moisture throughout the area and a condition of complete saturation, that is, $m=1$ in eq 2 . Uniform moisture conditions throughout the area are probably not a realistic situation, however we make this assumption to simplify the model because we are using data from many different storm-triggered events whose spatial moisture distributions varied in complicated patterns governed by the rainfall distributions from the various storms. We assume complete saturation, which is also probably not a common occurrence, but assuming some other saturation value $(\mathrm{m}=0.8$ or 0.6$)$ makes no difference in the correlation of the FS values with the actual failures from the data set. Predictably, the greatest concentrations of low FS values are on the steep bluffs adjacent to Puget Sound. Combinations of the steepest slopes and the lowest shear strengths yield the lowest FS values indicated by red and magenta colors.

In addition to steep slopes adjacent to Puget Sound, other steep slopes also show similar colors of low FS where streams have eroded steep-sided gullies and ravines into the landscape. Low FS values are also prevalent where artificial fill has been placed without significant compaction and allowed to form steep slopes.

\section{Distribution of Shallow Landslides with Susceptible Units}

Low FS values and a majority of the landslide-location data points are located within four geologic units: Landslide deposits (Q1s), Vashon advance glacial outwash deposits (Qva), Vashon Till (Qvt), and Mass-Wastage deposits (essentially landslide deposits, Qmw). Qva and Qvt commonly crop out in many of 

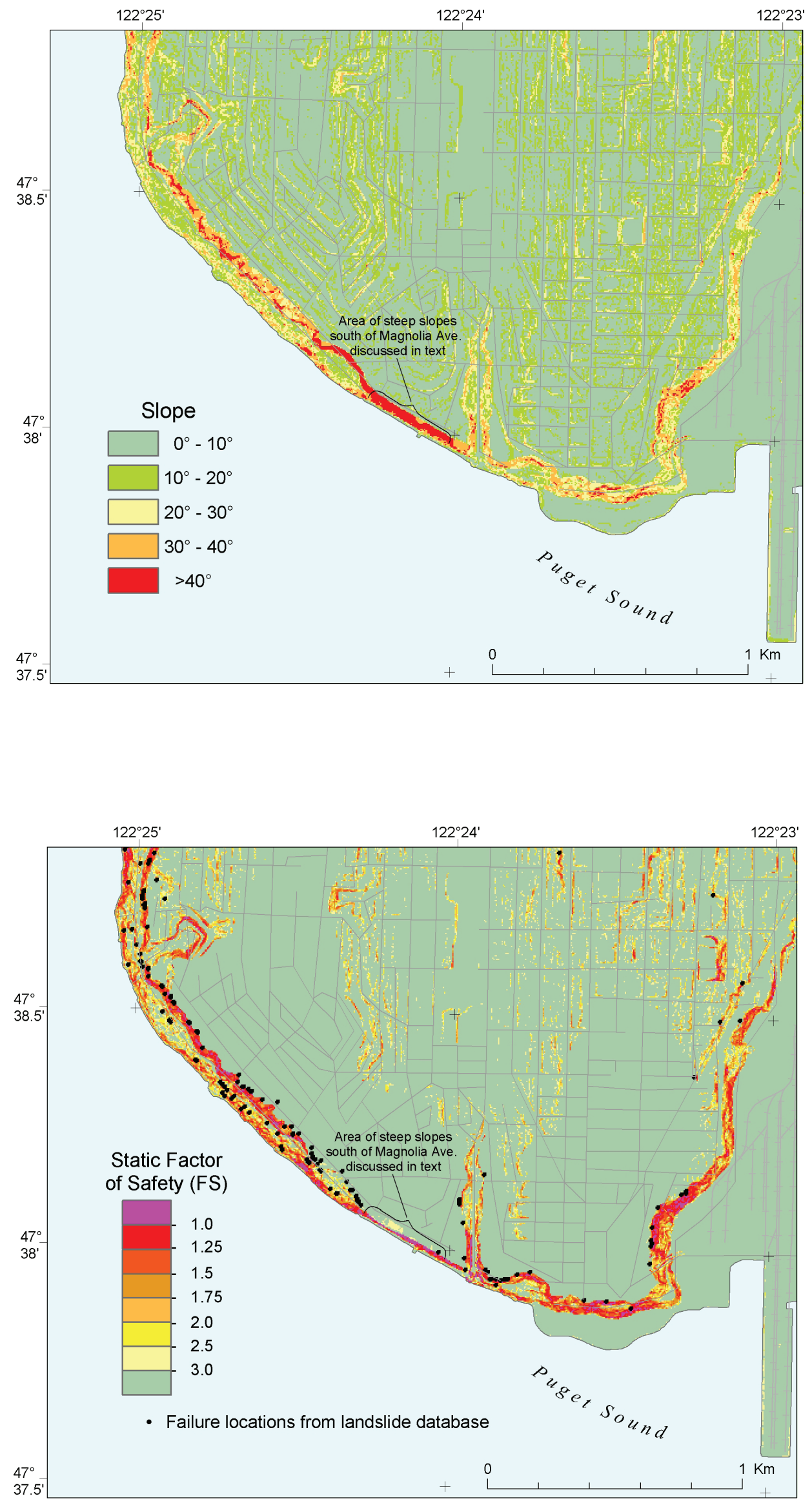

Figure 6. Slope map of southwest portion of Magnolia area in Seattle.

Figure 7. Shallow landslide susceptibility map of southwest portion of Magnolia area in Seattle depicting FS values of cells. 
the steeper slopes of the Seattle area. Qva, generally referred to as the Esperance Sand, is commonly located near the tops of bluffs in the Puget Sound area, which are popular residential homesites because of the spectacular views available from these sites. Also, Qva, as well as Qvlc and Qpf, commonly underlie many of the slopes mapped as Q1s and Qmw and thus form the parent material for these deposits. In addition, a majority of the points of the landslide dataset are actually in colluvium derived from weathered bedrock. If colluvium were a mapped unit, we would have used shear strengths appropriate to colluvium. Unfortunately, colluvium is not a mapped unit, hence we used the shear strengths of the parent materials. However, the shear strength of colluvium we would have used would be essentially the same as shear strength values used for landslide and masswastage deposits, and these units are extensively collocated with colluvium.

\section{Statistical Distribution of Shallow Landslides with Factor of Safety}

In using the dataset of shallow landslide locations, it must be noted that the reporting of landslides triggered by storms in Seattle has been somewhat uneven due to the population distribution. Public parks and other areas that have had numerous landslides through the years have had few reports because these areas are sparsely inhabited or uninhabited. Thus, some areas of Seattle with high susceptibility to shallow landslides show few, or no failure locations, from the landslide dataset due to this variability in reporting.
Plotting the distribution of shallow landslide source areas (point sources) from the landslide dataset versus FS shows that the number of shallow landslides peaks at a FS window of 1.0-1.5 and decreases rapidly as FS increases (fig. 8). Because the simple model we use is not exact, some shallow landslides from the data set are distributed in statistical bins higher than $\mathrm{FS}=1.0$ or even $\mathrm{FS}=1.5$. Dividing the number of shallow landslides within each of the statistical bins of FS by the total area included within each respective bin, allows calculation of the number of landslides per square kilometer for each FS bin (fig. 9A). This comparison of landslide concentrations essentially constitutes relative hazard. For example, $\mathrm{FS}=1.0-1.5$ has a concentration of approximately 100 landslides $/ \mathrm{km}^{2}$ while $\mathrm{FS}=1.5-2.0$ has a concentration of only 47 landslides $/ \mathrm{km}^{2}$. Therefore, it follows that the FS range 1.01.5 is twice as hazardous as the FS range 1.5-2.0. Constructing a regression equation to model this data set as an exponential function as shown in fig. $9 \mathrm{~B}$, yields an $\mathrm{R}^{2}$ value of greater than 90 percent. Over the length of this study, several versions of the factor-of-safety map have been produced corresponding to several additions to the data set as storms have produced shallow landslides in recent years. With each of these versions, the resulting maps and their statistics have changed little. Thus, the model appears to be valuable as a predictive tool for future shallow-landslide hazard.

If the data set for Seattle contained mapped debris-flow polygons instead of point locations, then the hazard could be portrayed as spatial probability or the percent chance of having a debris flow occur within an area covered by a particular range

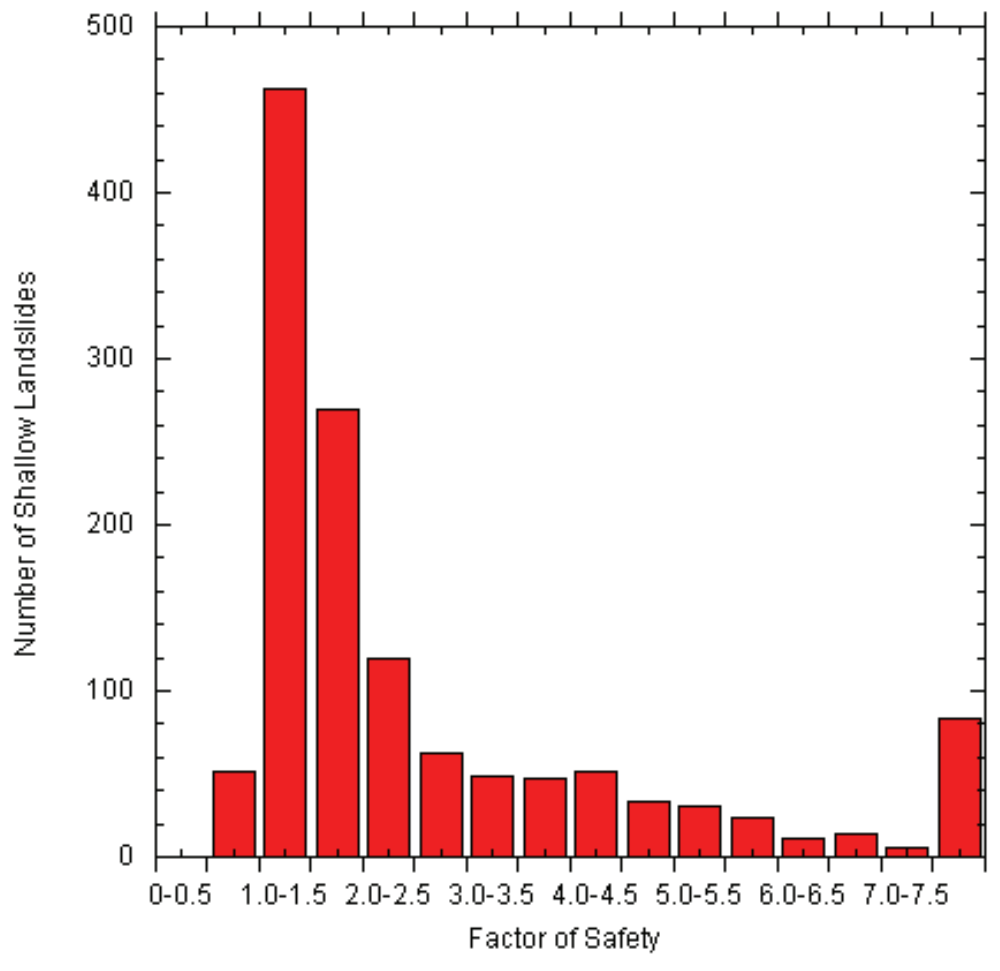

12
Figure 8. Bar chart showing number of shallow landslides from Seattle landslide data set versus FS value. 
of FS. Because the data set only consists of point locations, areal percentages are not possible, and the various debris-flow concentrations can only be evaluated with respect to each other. These concentration levels can be compared to those within bins that have FS values of 6.0 or greater and have few or no debris flows within their areas. Areas of high FS value are relatively stable, generally flat-lying, and provide an end member of the stability spectrum of possible slopes.

\section{Comparison of Factor of Safety with Variable Strength Properties versus Slope alone as a Predictor of Hazard}

To compare the predictive ability of Factor of Safety to that of slope alone, we conducted a similar Factor-of-Safety analysis as described in the previous sections with slope as the only variable. The shear strength components, $c^{\prime}$ and $\phi^{\prime}$ were held constant at $c^{\prime}=14.4 \mathrm{kPa}$ and $\phi^{\prime}=30^{\circ}$. The distribution of shallow landslide density versus FS for this condition is shown in fig. 10A. A visual comparison with fig. $9 A$ reveals a striking similarity. An exponential regression curve similar to that in figure $9 \mathrm{~B}$ is fit to these data and shown in fig. $10 \mathrm{~B}$. The fit of these data with the curve yields an $\mathrm{R}^{2}=0.86$. From the histograms and regression curves plotted in figs. 9 and 10, it is obvious that the model using variable shear strengths for the different geologic units is a slightly superior predictor of shallow landslide density or relative hazard. The model using slope as the only variable is almost as effective as that using differing shear strengths when considering only the statistics themselves. Why then use a more complicated model with differing material properties if only modest improvement in statistical prediction is achieved?

The answer to this question lies in the details of spatial information provided by the susceptibility map shown in fig. 7 and Map Sheet 1, the slope map shown in fig. 6, and the geologic map shown in fig. 5. Within the area of steep slopes in these figures (shown in brackets) just to the south of Magnolia Avenue, the bluffs consist of Vashon Till, one of the stronger units in the Seattle area. This is an area where FS values are mostly greater than 3.0 and where only one debris flow (black dot) is located from the data set, clearly an area of relative stability. Yet the slope map (fig. 6) shows this area as having slopes in excess of $40^{\circ}$, one that would be labeled as high susceptibility or hazard based on slope alone. The model using slope alone as a variable cannot discriminate FS based on material strength. It portrays these source areas as having low FS values, high susceptibility, and is completely in error. Also, the model with slope alone as a variable will not discriminate areas of relatively low slope where extremely weak geologic units exist, where FS values can range from 1.0 to 2.0 due to low cohesion or friction angle. Errors such as these, although involving relatively small areas, do affect densely populated urban portions of the city. From this example, we see that the locations where FS values are estimated are just as important as the overall statistical effectiveness of the model. For this reason, a model using variable shear strengths as well as slope is preferable because it avoids the mistakes made by the model using slope alone where it ignores the effects of stronger or weaker geologic units.

\section{Statistical Distribution of Data in Time}

The landslide data set for Seattle spans a time period of 114 years. The two FS bins, 0.5-1.0 and 1.0-1.5 each have a concentration of approximately 100 shallow landslides $/ \mathrm{km}^{2}$ (fig. $9 A)$. Dividing these concentrations by the total timespan (114 years) of the data set shows that each square kilometer having FS values within these two FS bins has 0.91 and 0.88 failures per year per square kilometer, or approximately one failure per year per square kilometer, as an average frequency of failure. This frequency is similar to that found by Coe and others (2004) for the areas of steepest slopes. Dividing by the total timespan of the data set assumes a uniform distribution of failures in time rather than a distribution associated with specific storm events. However, if we look at the distribution of the failures through time, we see the data clustered about specific years (fig. 11) when severe storm events occurred. The three years having the greatest number of failures were 1933, 1986, and 1997. The relatively high numbers of failures reported in 1986 and 1997 probably reflect more accurate and complete reporting in later years in addition to high numbers of failures.

\section{Problems Introduced by Urban Features}

The urban landscape introduces its own topography as it overlies or excavates into the natural slopes. Urban development also introduces artificially weakened or reinforced slopes often in close juxtaposition. Because of this often intricate spatial intermixing of materials having widely differing strengths, we have not been able to accurately characterize some slopes. A particular example of this is evident in the upland residential areas of Seattle where most of the houses have yards that are bounded by vertical rock retaining walls of about $1 \mathrm{~m}$ height. Because these slopes are vertical or nearly so, they show up as red and magenta ( $\mathrm{FS}=1.0$ or less) on the susceptibility map (Map Sheet 1). In reality, however, the FS values are much higher than 1.0 because of the retaining walls made out of interlocking basalt blocks or concrete, which are not mapped.

\section{RUNOUT LENGTHS OF SHALLOW LANDSLIDES}

All of the data discussed and analyzed above refer to initiation points or source areas of slope failures. However, just as relevant to the hazard situation presented by shallow landslides is the runout distance for those that transform into debris flows. Although we have no runout data for the failures in this data set, we do have a map of debris flows, their travel paths, and other types of landslides that were produced during the winter of 1996/97, most of which occurred during two precipitation events, on January 1 and March 18. Most of the failures in this data set are debris flows and were mapped from stereo aerial photography acquired in April 1997 and plotted on 1: 24,000- 

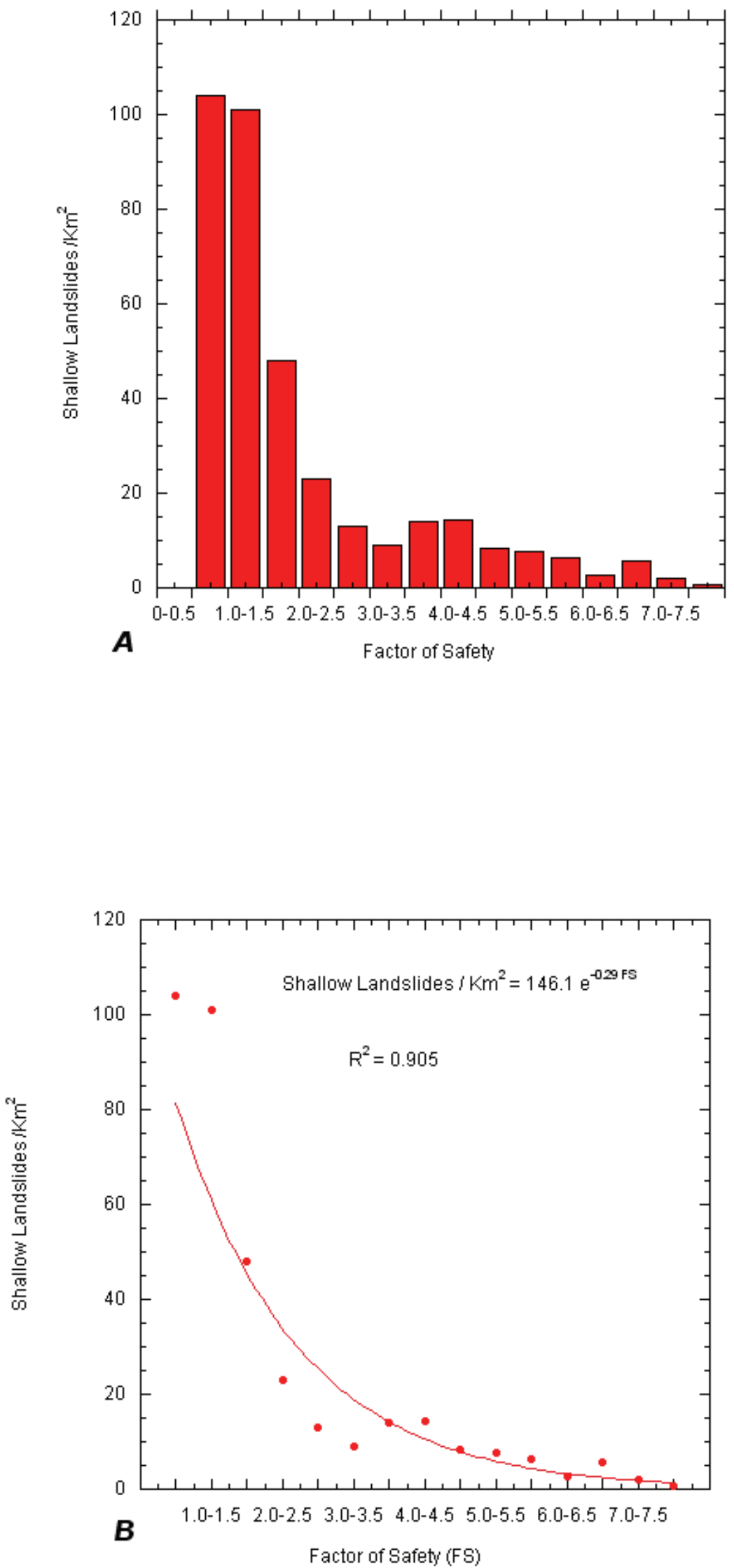

Figure 9. A, Bar chart showing number of shallow landslides per square kilometer from Seattle landslide data set versus FS value. $B$, Scatter plot of the data in $A$ with an exponential curve fit to the data. 

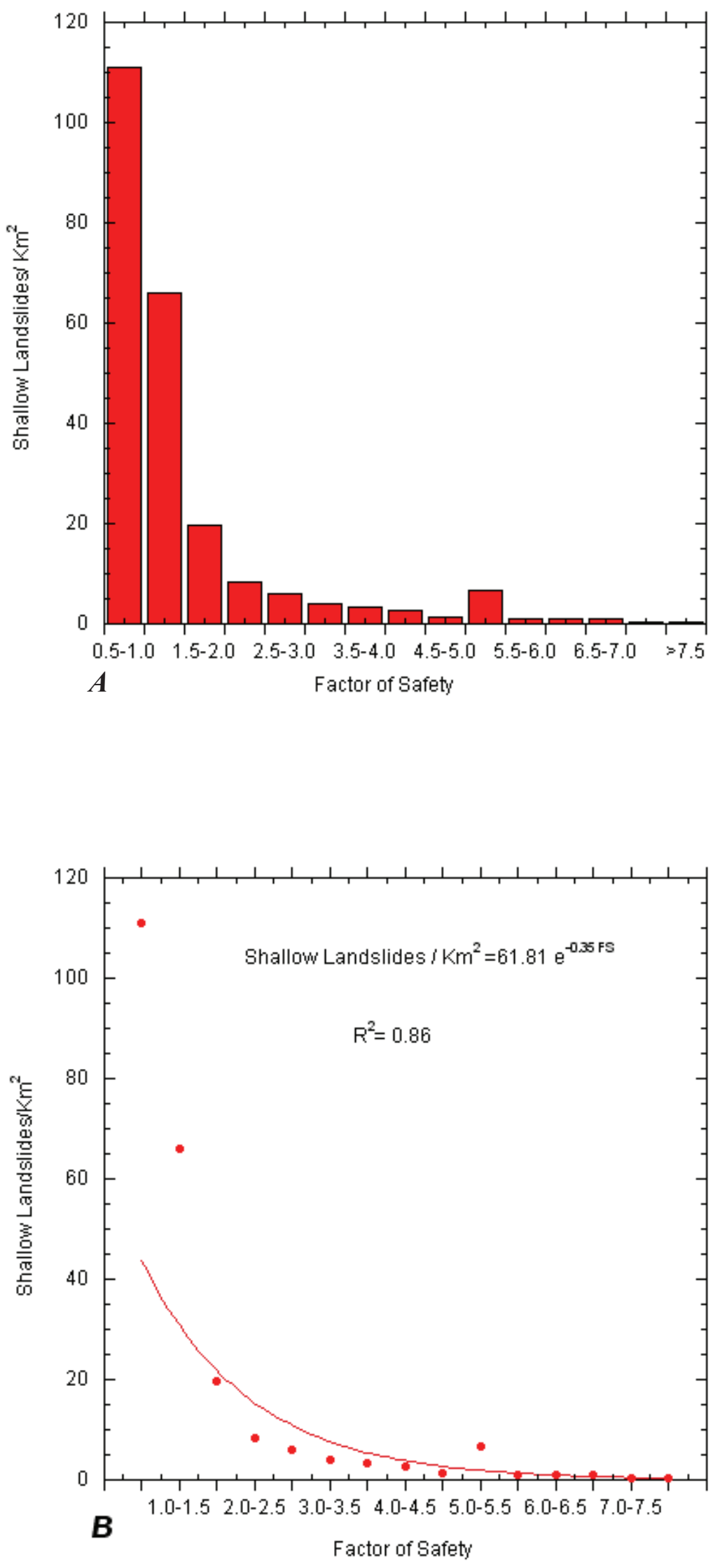

Figure 10. A, Bar chart showing number of shallow landslides per square kilometer from Seattle landslide data set versus FS value with shear strength held constant. $B$, Scatter plot of the data in $A$ with an exponential curve fit to the data. 


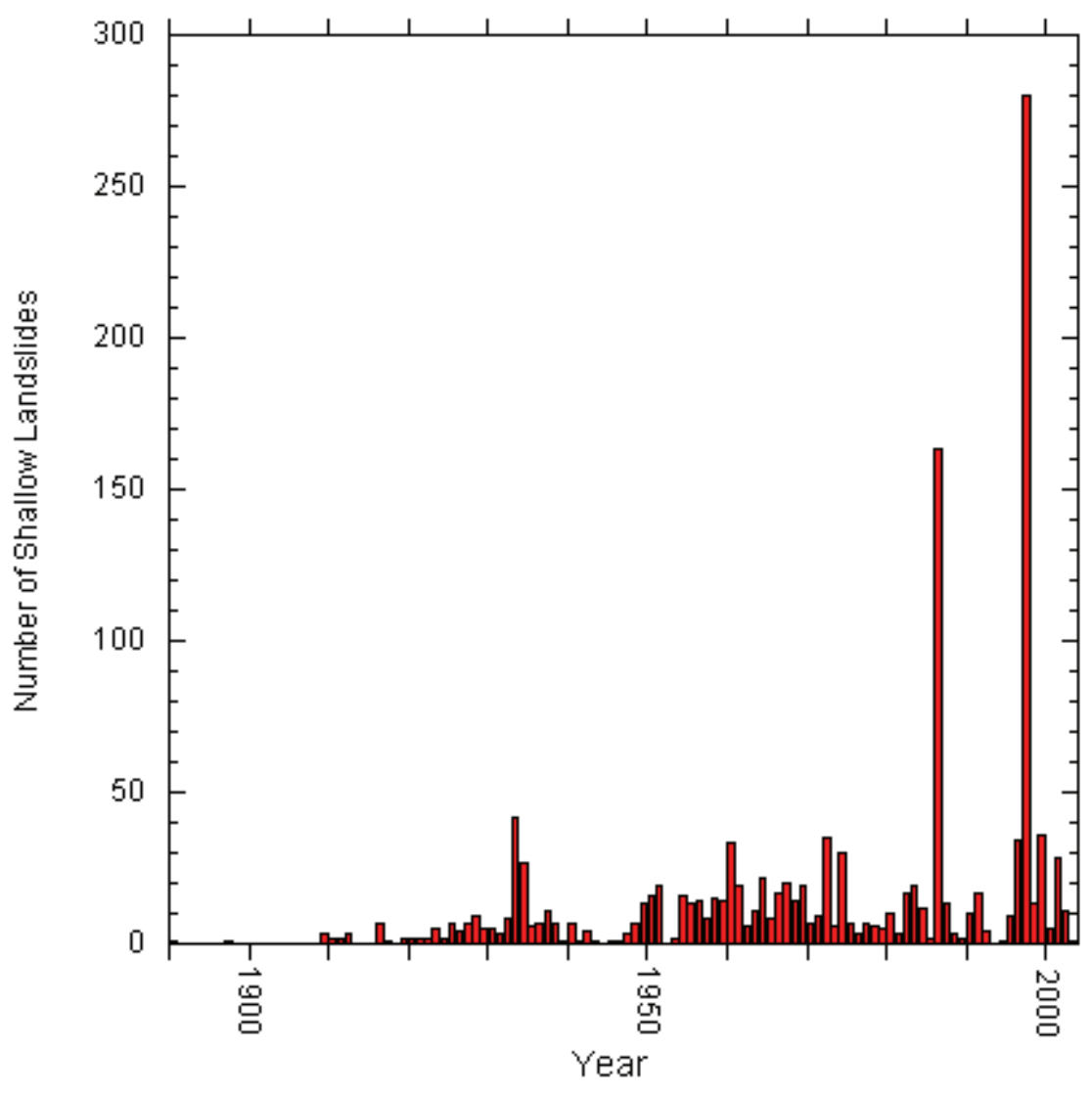

Figure 11. Bar chart showing the number of shallow landslides from the Seattle landslide data set versus the year of occurrence.

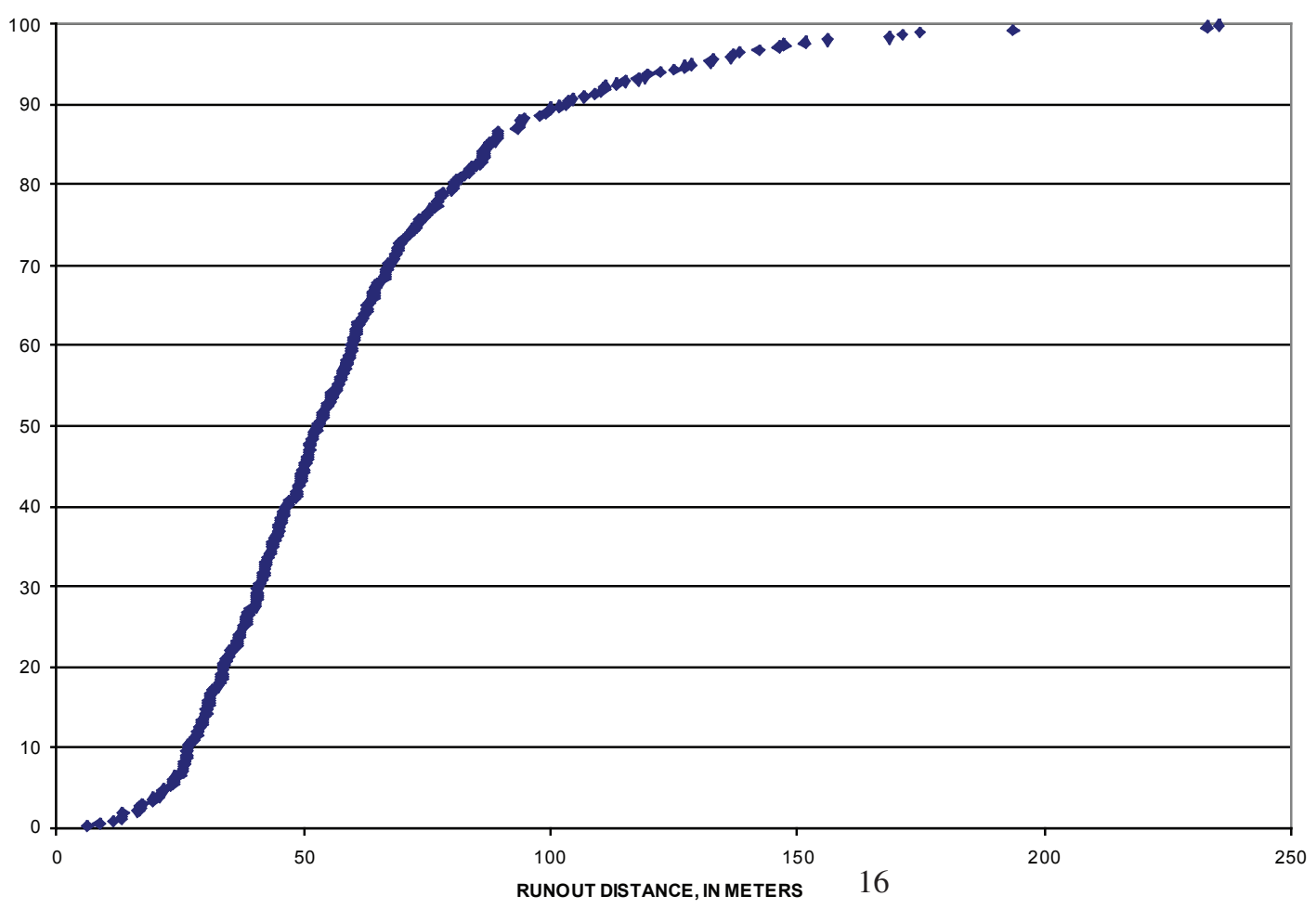

Figure 12. Cumulative frequency plot of runout distances for the 326 debrisflow runout lengths mapped from north Seattle to Everett. 
scale USGS topographic maps (Baum and others, 2000). Except for large failures, such as the Woodway slump/debris flow, few debris flows crossed the Burlington Northern-Santa Fe railroad tracks and embankment which presented a significant barrier to debris-flow runout at the base of the slopes. Also, nearly all of the flat terrain at the base of the slopes is at, or seaward, from the shoreline of Puget Sound.

The mapped area consists essentially of the coastal bluffs along Puget Sound from north Seattle to Everett, Washington. Within this corridor along the bluffs, 326 debris flows and other landslides were mapped and their dimensions measured. The minimum length of these failures from headscarp to toe is about 6 $\mathrm{m}$. The maximum length is about $235 \mathrm{~m}$. The mean length is 60.2 $\mathrm{m}$ while the median is $52.6 \mathrm{~m}$. The standard deviation from the mean is $\pm 34.1 \mathrm{~m}$. The distribution of runout lengths within this data set is shown in fig. 12 (Baum, unpub. data). The slopes along this section of Puget Sound are representative of Puget Sound coastal bluffs throughout Seattle. Typical slope lengths range from less than $100 \mathrm{~m}$ to sections where lengths are greater than $1,000 \mathrm{~m}$. Therefore, in some areas, debris flows with mean runout lengths will extend across most of the length of the slope. In other areas, the maximum runout length from this data set is less than the length of slope.

Models of granular or particle flow have been used to attempt to match the distances and paths of debris flows (Hungr and Morgenstern, 1984; Denlinger and Iverson, 2004; Iverson and others, 2004). However, no current models accurately model runout distances except in uniform materials that contain few irregular particles. Trees and other types of vegetation that commonly become incorporated in debris flows in the Seattle area are irregularities that cannot be modeled successfully by these methods but can impart considerable influence on runout distances and flow paths. Therefore, the most accurate information available on runout lengths is that from actual debris flows, and although the data set from January/March 1997 only represents two storm events, the runout lengths that it yields are the best information that we have to evaluate the hazard presented by the travel paths of debris flows in Seattle.

Although most of the source areas for debris flows are located near the tops of slopes in the Seattle area, debris-flow sources are scattered among lower parts of the slopes as well. There are enough of these that a runout zone established below susceptible cells based on the mean or maximum runout length from this data set would cover most of the existing slopes. For this reason, we conclude that the runout data indicate that all areas of steep slopes forming bluffs of Puget Sound and along other bluffs in the Seattle area should be considered hazardous. Furthermore, where flat-lying areas exist in Seattle below steep slopes that are above water and can be occupied, a runout zone based on the mean $(60.2 \mathrm{~m})$ or maximum $(235 \mathrm{~m})$ runout length would provide a degree of protection for the runout areas of most of the existing slopes of concern.

\section{SHALLOW-LANDSLIDE HAZARD MAP}

The distribution of shallow landslide concentration values as a function of factor of safety (fig. 9A) was used to establish relative hazard categories for shallow landslide source areas. Fig. 9A shows that the data can be divided into three obvious categories of hazard: $\mathrm{FS}=0.5-1.5$ ( $>75$ shallow landslides $\left./ \mathrm{km}^{2}\right)$ is the highest category, FS $=1.5-2.5$ (20-75 shallow landslides $\left./ \mathrm{km}^{2}\right)$ is a medium category, and the remainder of the data, FS $>2.5,(<20$ shallow landslides $/ \mathrm{km}^{2}$ ), is in a category of low relative hazard. Other placements of FS boundaries could be constructed to define four or five categories of hazard instead of just three. It is worth mentioning here that the category of medium relative hazard, with an upper FS limit of 2.5 corresponds, in most cases, to a $20^{\circ}$ slope threshold, which has been, and continues to be used, as a regulatory threshold in the city of Seattle.

A map based on a three-category hazard model outlined above is shown in fig. 13 and on Map Sheet 2. This map can now be used by the city of Seattle for planning purposes related to public utilities, city infrastructure, land use, and emergency response during severe shallow landslide-triggering storms (for example, $>2 \mathrm{~mm} / \mathrm{hr}$ rainfall for 24 hours; Godt and others, 2006). As city agency personnel become familiar with both the susceptibility and hazard maps, they also can use the maps in a regulatory capacity to support land-use policy. With such a high correlation between the map categories of shallow landslide susceptibility and the historical data set, the city has an extremely robust model upon which to base planning and policy decisions.

\section{SUMMARY AND CONCLUSIONS}

A simple infinite-slope analysis has been used together with a historical landslide data set collected for the city of Seattle, Washington, to establish a reliable correlation between a slopestability measure (factor of safety, FS) and the locations of shallow slope failures that form debris flows.

The resulting FS map (Map Sheet 1) of the city shows the lowest FS values in areas where slopes are steep and where geologic units have low shear strengths. The majority of these areas are along the steep bluffs of Puget Sound, such as the Magnolia area (figs. 5-7, fig. 13) and the slopes above Alki Avenue W. in west Seattle (Map Sheet 1). However, many inland areas are also highly susceptible to shallow landslide failure. Areas of numerous low FS values include the Madrona area along the western shore of Lake Washington and many of the slopes adjacent to Lake Washington both to the north and south of this area. In general, many of the slopes that occupy the steep slopes of glacially formed ridges and hills within the Seattle area are sites of highly susceptible terrain.

The FS values of the susceptibility map (fig. 7, Map Sheet 1) were compared with the locations of failures from the landslide data set (fig. 8), and the resulting model of shallow landslide concentration versus FS (fig. 9B) shows excellent correlation with an $\mathrm{R}^{2}$ of greater than 90 percent. FS values calculated using slope as the only variable also show excellent correlation with shallow 


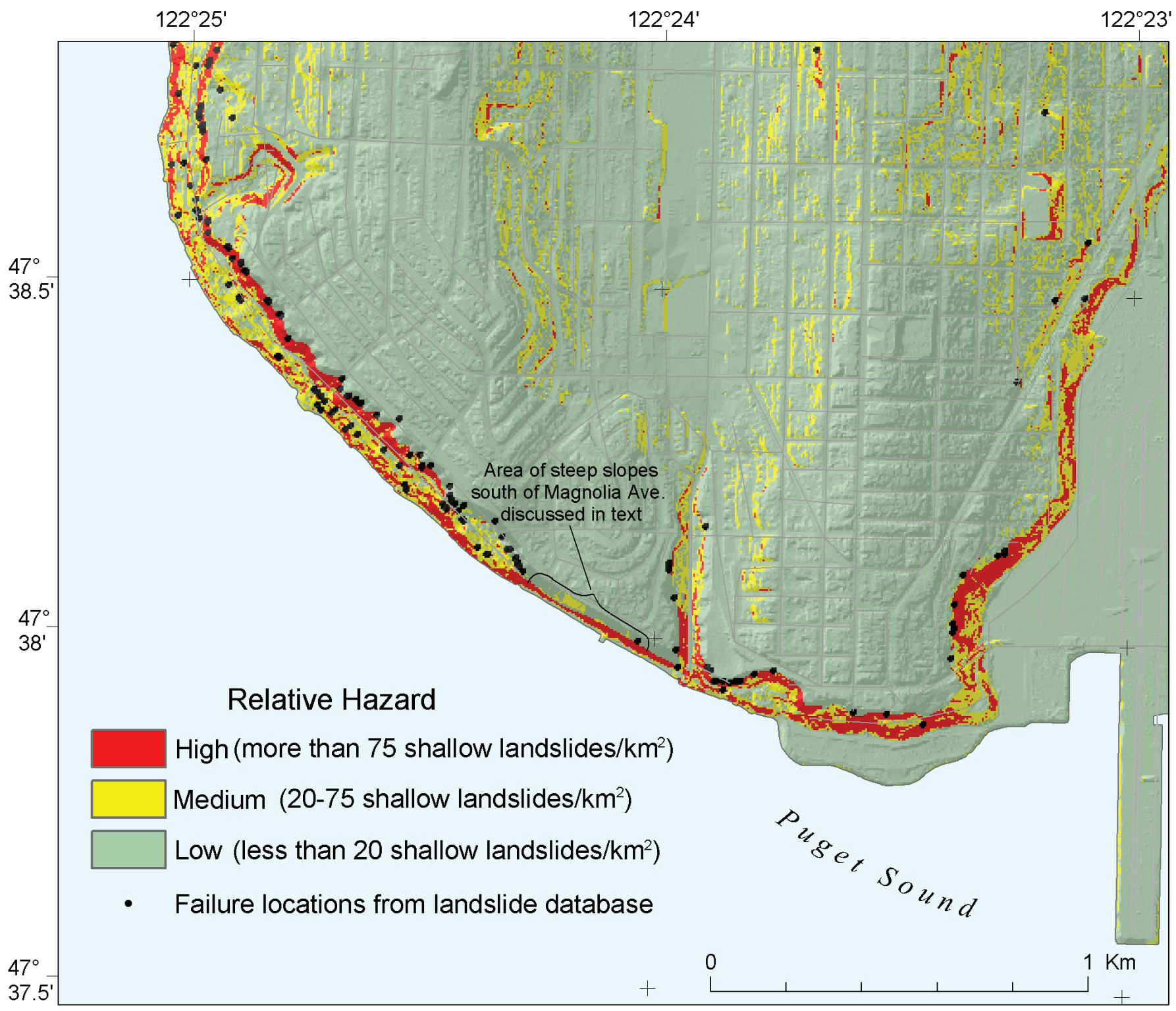

Figure 13. Map of relative shallow-landslide hazard for southwest portion of Magnolia area in Seattle. 
landslide concentration (figs. $10 A$ and $B$ ) and, in fact appear to be nearly as good, from a statistical standpoint, as those calculated using differing shear strengths. Montgomery and others (2001) also noted the effectiveness of slope alone as a predictor of slope instability in Seattle as it produced results comparable with SHALSTAB. However, as noted using figs. 5, 6, and 7, a slopestability model using slope as the only variable will inevitably lead to spatial errors in calculation of FS where relatively resistant units occupy steep slopes and relatively weak units occupy low slopes. For these reasons, we favor using a model that uses the additional discriminator based on material properties.

Based on the levels of shallow landslide concentration versus FS shown in fig. 9A, we established three categories of shallowlandslide hazard: high, medium, and low. This map (Map Sheet 2) will allow Seattle city officials and planners to make decisions regarding areas of shallow-landslide hazard within the city. As development proceeds, portions of these maps will become outdated and will need to be updated with different shear-strength and slope attributions as construction and grading change the susceptibility of these areas. With its own mapping and GIS facilities, the city of Seattle can use its expertise and knowledge of ongoing construction activities to keep pace with the changing face of the city and keep the maps of susceptibility and relative hazard current.

\section{ACKNOWLEDGMENTS}

The city of Seattle provided the landslide data set and many other data sets during this study. The city government and its leaders have taken a proactive stance in encouraging the preparation of these maps. Jim Mullen, emergency response coordinator for Seattle (now for the State of Washington) provided leadership in guiding Project Impact in Seattle and for stimulating the undertaking of this study. Ines Pearce gave continued encouragement and support throughout the course of the study and provided excellent communication between us and the ultimate users of the maps. Cheryl Paston and William Benzer of the Seattle Engineering Department, provided support and coordination of the information dissemination between us and the various city departments likely to use the maps. Tom Nolan and Ken Conradi of Seattle Public Utilities gave assistance with both technical issues and coordination with city departments. The Puget Sound LIDAR Consortium provided the recent LIDAR data set of the Seattle area.

Kathy Troost and Derek Booth assisted with stratigraphic information regarding the most recent geologic map and answered queries regarding glacial sediments of the Puget Lowland. Craig Weaver gave encouragement and support in involving us with the city of Seattle so that the investigation could be undertaken, and provided continuing assistance with logistical matters throughout the project. Jim Wu of Shannon and Wilson, Inc. provided shear-strength data without which the model could not be applied to the city slopes. David Perkins of the USGS suggested using relative hazard as a comparative tool. Randy Jibson, Mark Reid, Jeff Coe, and Rex Baum of the USGS reviewed the manuscript and provided helpful suggestions for its improvement.

\section{REFERENCES CITED}

Baum, R.L., Savage, W.Z., and Godt, J.W., 2002, TRIGRS-A Fortran program for transient rainfall infiltration and gridbased regional slope-stability analysis: U.S. Geological Survey Open-File Report 02-0424, 27 p. 2 Appendices. http://pubs.usgs.gov/of/2002/ofr-02-424/

Baum, R.L., Harp, E.L., and Hultman, W.A., 2000, Map showing recent and historic landslide activity on coastal bluffs of Puget Sound between Shilshole Bay and Everett, Washington: U.S. Geological Survey Miscellaneous Field Studies Map MF-2346, Scale 1: 24,000.

Baum, R.L., Chleborad, A.F., and Schuster, R.L., 1998, Landslides triggered by the winter 1996-97 storms in the Puget lowland, Washington: U.S. Geological Survey OpenFile Report 98-239, 9 p., 1 pl.

Coe, J.A., Michael, J.A., Crovelli, R.A., Savage, W.Z., Laprade, W.T., and Nashem, W.D., 2004, Probabilistic assessment of precipitation-triggered landslides using historical records of landslide occurrence, Seattle, Washington: Environmental and Engineering Geoscience, v. 10, no. 2, p. 103-122.

Denlinger, R.P., and Iverson, R.M., 2004, Granular avalanches across irregular three-dimensional terrain: 1 . Theory and computation: Journal of Geophysical Research, v. 109, F01014, doi:10.1029/2003JF000085.

Easterbrook, D.J., Crandell, D.R., and Leopold, E.B., 1967, PreOlympia Pleistocene stratigraphy and chronology in the central Puget Lowland, Washington: Geological Society of America, Bulletin, v. 78, p. 13-20.

FEMA Interagency Hazard Mitigation Team, 1996, February 1996, State of Washington winter storm of 1995-1996: Interagency Hazard Mitigation Team Report.

Fulmer, C.V., 1975, Stratigraphy and paleontology of the Blakely and Blakely Harbor Formations, in Weaver, D.W., Hornaday, G.R., and Tipton, A., eds., Paleogene symposium and selected techincal papers: conference on future energy horizons of the Pacific Coast: American Association of Petroleum Geologists Pacific Section 50 ${ }^{\text {th }}$ Annual Meeting, p. 210-271.

Galster, R.W., and Laprade, W.T., 1991, Geology of Seattle, Washington, USA: Bulletin Association Engineering Geologists, v. 28, no. 3, p. 235-302.

Godt, J.W., Baum, R.L., and Chleborad, A.F., 2006, Rainfall characteristics for shallow landsliding in Seattle, Washington, USA: Earth Surface Processes and Landforms, v. 31, no. 1, p. 97-110.

Hammond, C., Hall, D., Miller, S., and Swetik, P., 1992, Level I stability analysis (LISA) documentation for version 2 , General Technical Report INT-285, USDA Forest Service Intermountain Research Station, $121 \mathrm{p}$. 
Haneberg, W.C., 2005, Influence of digital elevation model errors on the reliability of maps depicting earthquake-triggered landslide hazards: Report to the National Earthquake Hazards Program for External Award 04HQGR0035: Haneberg Geoscience, Seattle, Washington, 48 p.

Harp, E.L., Held, M.D., Castañeda, M.R., McKenna, J.P., and Jibson, R.W., 2002, Landslide hazard map of Tegucigalpa, Honduras: U.S. Geological Survey Open-File Report 02-219, 9 p., 2 pl., Scale 1:15,000.

Harp, E.L., Reid, M.E., and Michael, J.A., 2004, Hazard analysis of landslides triggered by Typhoon Chata'an on July 2 , 2002, in Chuuk State, Federated States of Micronesia: U.S. Geological Survey Open-File Report 2004-1348, 22 p., 2 pl.

Hungr, O., and Morgenstern, N.R., 1984, Experiments on the flow behavior of granular materials at high velocity in an open channel: Geotechinique, v. 34, p. 405-413.

Iverson, R.M., Logan, M., and Denlinger, R.P., 2004, Granular avalanches across irregular three-dimensional terrain: 2 . Experimental tests: Journal of Geophysical Research, v. 109, F01015, doi:10.1029/2003JF000084.

Iverson, R.M., 2000, Landslide triggering by rain infiltration: Water Resources Research, v. 36, no. 7, p. 1897-1910.

Jibson, R.W., Harp, E.L., and Michael, J.A., 2000, A method for producing digital probabilistic seismic landslide hazard maps: Engineering Geology, v. 58, p. 271-289.

Laprade, W.T., Kirkland, T.E., Nashem, W.D., and Robertson, C.A., 2000, Seattle Landslide Study: Internal Report W7992-01, Shannon and Wilson, Seattle, WA, 164 p.

Lott, N., Ross, D., and Sittel, M., 1997, The winter of '96-'97 west coast flooding: National Climate Data Center Technical Report 97-01, 11 p.

Minard, J.M., and Booth, D.B., 1988, Geologic map of the Redmond 7.5' quadrangle, King and Snohomish Counties, Washington: U.S. Geological Survey Miscellaneous Field Investigations Map MF-2016, scale 1:24,000.

Montgomery, D.R., Greenburg, H.M., Laprade, W.T., and Nashem, W.D., 2001, Sliding in Seattle: Test of a model of shallow landsliding potential in an urban environment, in Wigmosta, M.S., and Burges, S.J., eds., Land Use and Watersheds: Human Influence on Hydrology and Geomorphology in Urban and Forest Areas: Water Science Application, American Geophysical Union, Washington, D.C., v. 2, p. 59-73.

Montgomery, D.R., and Dietrich, W.E., 1994, A physically based model for the topographic control on shallow landsliding: Water Resources Research, v. 30, no. 4, p. 1153-1171.
Morrissey, M.M., Wieczorek, G.F., and Morgan, B.A., 2001, A comparative analysis of hazard models for predicting debris flows in Madison County, Virginia: U.S. Geological Survey Open-File Report 01-67, 27 p.

Mullineaux, D.R., Waldron, H.H., and Rubin, M., 1965, Stratigraphy and chronology of late interglacial and early Vashon time in the Seattle area, Washington: U.S. Geological Survey Bulletin 1194-O, p. O1-O10.

Nashem, W.D., and Laprade, W.T., 1998, Landslides in Seattle-Historical documentation leads to future mitigation, in Program with Abstracts, Association of Engineering Geologists $41^{\text {st }}$ Annual Meeting, Seattle: Association of Engineering Geologists, College Station, TX, p. 113.

Pack, R.T., Tarboton, D.G., and Goodwin, C.N., 1999, GIS-based landslide susceptibility mapping with SINMAP: Proceedings of the $34^{\text {th }}$ symposium on Engineering Geology and Geotechnical Engineering, Bay, J.A., ed., p. 210-231.

Reid, M.E., 1997, Slope instability caused by small variations in hydraulic conductivity: Journal of Geotechnical and Geoenvironmental Engineering, v. 123, no. 8, p. 717-725.

Savage, W.Z., Godt, J.W., and Baum, R.L., 2004, Modeling time-dependent areal slope stability, in Lacerda, W.A., Ehrlich, M., Fontoura, S.A.B., and Sayão, A.S.F., eds., Landslides_-Evaluation and Stabilization: Proceedings of the $9^{\text {th }}$ International Symposium on Landslides, Rio de Janeiro, Brazil, v 1., p. 23-36.

Savage, W.Z., Morrissey, M.M., and Baum, R.L., 2000, Geotechnical properties for landslide-prone Seattle area glacial deposits: U.S. Geological Survey Open-File Report 00-228, 5 p.

Taylor, G.H., 1996, The great flood of 1996: Oregon climate service online report, http://www.ocs.oregonstate.edu/index. html.

Tubbs, D.W., 1974, Landslides in Seattle: Washington Division of Geology and Earth Resources Information Circular 52, Olympia, Wash., Washington Division of Geology and Earth Surface Resources, 15 p., 1 pl.

Troost, K.G., Booth, D.B., Wisher, A.P., and Shimel, S.A., 2005, The geologic map of Seattle-A progress report: U.S. Geological Survey Open-File Report 2005-1252, scale $1: 24,000$, digital file at 1:12,000.

Vine, J.D., 1962, Stratigraphy of Eocene rocks in a part of King County, Washington: Washington Div. Mines and Geology Report of Investigaation 21, $20 \mathrm{p}$.

Weaver, C.A., 1916, The Tertiary formations of western Washington: Washington Geological Survey Bulletin, no. 13, $327 \mathrm{p}$. 